\title{
The TNFR family members OX40 and CD27 link viral virulence to protective T cell vaccines in mice
}

\author{
Shahram Salek-Ardakani, ${ }^{1}$ Rachel Flynn, ${ }^{1}$ Ramon Arens, ${ }^{2}$ Hideo Yagita, ${ }^{3}$ Geoffrey L. Smith, ${ }^{4}$ \\ Jannie Borst, ${ }^{5}$ Stephen P. Schoenberger, ${ }^{2}$ and Michael Croft ${ }^{1}$

\begin{abstract}
${ }^{1}$ Division of Molecular Immunology and 2Division of Developmental Immunology, La Jolla Institute for Allergy and Immunology, La Jolla, California, USA. ${ }^{3}$ Department of Immunology, Juntendo University School of Medicine, Tokyo, Japan. ${ }^{4}$ Department of Virology, Imperial College London, London, United Kingdom. 5Division of Immunology, The Netherlands Cancer Institute, Amsterdam, The Netherlands.
\end{abstract}

\begin{abstract}
Induction of $\mathrm{CD8}^{+} \mathrm{T}$ cell immunity is a key characteristic of an effective vaccine. For safety reasons, human vaccination strategies largely use attenuated nonreplicating or weakly replicating poxvirus-based vectors, but these often elicit poor $\mathrm{CD8}^{+} \mathrm{T}$ cell immunity and might not result in optimal protection. Recent studies have suggested that virulence is directly linked to immunogenicity, but the molecular mechanisms underlying optimal $\mathrm{CD8}^{+} \mathrm{T}$ cell responses remain to be defined. Here, using natural and recombinant vaccinia virus (VACV) strains, we have shown in mice that VACV strains of differing virulence induce distinct levels of T cell memory because of the differential use of TNF receptor (TNFR) family costimulatory receptors. With strongly replicating (i.e., virulent) VACV, the TNFR family costimulatory receptors OX40 (also known as $\mathrm{CD134}$ ) and CD27 were engaged and promoted the generation of high numbers of memory $\mathrm{CD8}^{+} \mathrm{T}$ cells, which protected against a lethal virus challenge in the absence of other mechanisms, including antibody and help from $\mathrm{CD}^{+} \mathrm{T}$ cells. In contrast, weakly replicating (i.e., low-virulence) VACV strains were poor at eliciting protective $\mathrm{CD8}^{+} \mathrm{T}$ cell memory, as only the Ig family costimulatory receptor $\mathrm{CD} 28$ was engaged, and not $\mathrm{OX} 40$ or CD27. Our results suggest that the virulence of a virus dictates costimulatory receptor usage to determine the level of protective $\mathrm{CD8}^{+} \mathrm{T}$ cell immunity.
\end{abstract}

\section{Introduction}

A desirable vaccine should elicit strong, long-lasting humoral and cellular immunity. While all human vaccines provide protection against disease via the generation of antibody responses, increasing attention is being focused on the idea that populations of memory $\mathrm{CD}^{+} \mathrm{T}$ cells are essential for protection from pathogens for which vaccine development has been unsuccessful thus far, such as HIV, malaria, tuberculosis, and herpes simplex virus. For safety reasons, many vaccination strategies use replication-incompetent, or replication-competent highly attenuated, poxvirus-based vectors. However, there is considerable literature acknowledging that highly replicative viruses are better at inducing $\mathrm{CD}^{+} \mathrm{T}$ cell responses. Animal and nonhuman primate studies have suggested that multiple dosing, or higher dosing, with replication-incompetent highly attenuated poxviruses is required to achieve $\mathrm{T}$ cell responses, and sometimes antibody responses, comparable to those elicited by replicationcompetent or highly virulent poxviruses $(1-10)$. Although this is logically related to antigen load or the persistence of antigen to stimulate $\mathrm{CD}^{+} \mathrm{T}$ cells, the effect of reduced virulence on immunogenicity becomes a major issue when attempting to derive a truly effective vaccine that incorporates attenuated vectors.

Vaccinia virus (VACV) represents a relevant example of the importance of understanding how attenuated pathogens might behave as vaccines. Since the successful eradication of smallpox 3 decades ago, a large effort has been made to develop secondand third-generation highly attenuated poxvirus-based vectors

Conflict of interest: The authors have declared that no conflict of interest exists. Citation for this article: J Clin Invest. 2011;121(1):296-307. doi:10.1172/JCI42056 as vaccine vehicles for other infectious diseases, including herpes simplex virus, SARS, influenza, HIV, tuberculosis, and malaria, as well as for cancer immunotherapy (11-13). These include modified VACV Ankara (MVA) (14), a variant of Lister strain LC16m8; ACAM1000/2000, derived from New York City Board of Health strain NYCBOH; the highly deleted Copenhagen VACV strain derivative NYVAC; and attenuated canarypox virus (ALVAC). Although some vectors given by certain routes might result in strong $\mathrm{CD}^{+} \mathrm{T}$ cell responses, the literature also suggests there is variability in the levels of $\mathrm{CD}^{+} \mathrm{T}$ cell immunity, raising the question of what determines induction of optimal $\mathrm{CD}^{+} \mathrm{T}$ cell responses $(2,7-10,15-17)$. Using several clinically relevant natural and recombinant VACV variants, we show here a quantitative difference in $\mathrm{CD}^{+} \mathrm{T}$ cell immunity elicited depending on the virus and immunization route, with only the most virulent VACVs promoting protective populations of memory $\mathrm{CD}^{+} \mathrm{T}$ cells. This enhanced $\mathrm{CD}^{+} \mathrm{T}$ cell memory was dependent on OX40 (also known as CD134) and CD27, 2 of the many stimulatory receptors in the TNF receptor (TNFR) superfamily that can be expressed on T cells $(18,19)$. Importantly, OX40 and CD27 were only operative with a VACV strain that could replicate strongly; when higher doses of attenuated VACVs were used for inoculation; or when attenuated VACV was given via an immunization route that allowed for strong replication. In contrast, only CD28/B7 interactions, but not OX40/OX40L or CD27/CD70 interactions, were used in generating responses to VACVs that were cleared quickly; consequently, $\mathrm{CD}^{+} \mathrm{T}$ cell memory was substantially weaker and did not afford protection in the absence of $\mathrm{CD}^{+} \mathrm{T}$ cell help and antibody. These data provide an explanation for why poxvirusbased vaccines can result in good $\mathrm{CD}^{+} \mathrm{T}$ cell immunity and 
provide a framework for understanding which molecular interactions to target when using attenuated vaccines to provide the best methodologies to vaccinate individuals against pathogen attack.

\section{Results}

Virulence correlates with the generation of persistent $V A C V$-specific $C D 8^{+}$ Tcell populations. Numerous VACV strains have been isolated, including the prototypical strain used in the laboratory, Western Reserve (WR), as well as others such as Lister (used as a smallpox vaccine in Europe) and the New York City Board of Health strain (NYCBOH) used as a smallpox vaccine in the United States (Dryvax, produced by Wyeth). All viruses are known to differ in expression of several virulence factors, although the exact extent of variation is not fully documented. For example, the VACV WR encodes B18R, which produces an IFN-I-binding protein that neutralizes this cytokine. Lister does not possess this gene, and $\mathrm{NYCBOH}$ produces a truncated $\mathrm{B} 18 \mathrm{R}$ gene product that is inactive (20). Another difference is the activity targeting the IL-1 $\beta$-converting enzyme encoded by the B13R gene that is found in WR, but is produced as a truncated protein in $\mathrm{NYCBOH}$ and not present in Lister (21). As a direct example of an engineered attenuated vaccine vector, we also used a mutant WR strain in which only the B18R gene was deleted (22), referred to herein as WR-B18R.

When infection was i.p., WR was slowly cleared, with a strong reduction in viral load only obvious between days 14 and 15 , whereas NYCBOH and Lister were cleared by day 3 in the spleen and day 7 in the ovaries (Figure 1A). WR-B18R exhibited intermediate characteristics, with reduced titers in the spleen between days 3 and 4 , and moderately lower titers compared with WR in the ovaries at day 7. To further demonstrate altered virulence between these strains, mice were exposed to i.n. virus at varying doses (Figure 1B). Whereas even a low dose of $10^{4}$ PFU WR was not controlled well, resulting in severe weight loss, $10^{6} \mathrm{PFU}$ Lister, NYCBOH, or WR$\mathrm{B} 18 \mathrm{R}$ was not pathogenic, and little to no weight loss was observed. This was not dependent on the background of the host, as similar results were obtained after i.p. or i.n. infection of BALB/c mice (Supplemental Figure 1; supplemental material available online with this article; doi:10.1172/JCI42056DS1). Thus, in i.p. and i.n. infection models, the VACVs WR-B18R, Lister, and NYCBOH were highly attenuated compared with the native VACV WR.

To assess induction of $\mathrm{CD}^{+} \mathrm{T}$ cell memory, the immunodominant VACV-reactive $\mathrm{CD} 8^{+} \mathrm{T}$ cell population was tracked with a tetramer of a peptide of B8R (23-25) or through the production of IFN- $\gamma$ following stimulation with vaccinia epitopes. At 40 days after i.p. infection, the frequency of memory B8R tetramer-reactive (i.e., B8R ${ }^{+} \mathrm{CD}^{+} \mathrm{T}$ cells (and $\mathrm{CD} 8^{+} \mathrm{IFN}-\gamma^{+} \mathrm{T}$ cells; data not shown) in both secondary lymphoid organs and peripheral organs such as the lung was 2- to 4-fold greater in mice infected with WR than in those infected with WR-B18R, Lister, or NYCBOH (Figure 2A). $\mathrm{T}$ cell avidity was also assessed by intracellular IFN- $\gamma$ staining of freshly isolated splenocytes from WR- and Lister-infected mice. At 40 days after infection, memory $\mathrm{CD}^{+} \mathrm{T}$ cells were stimulated for 6 hours with graded concentrations of $\mathrm{B} 8 \mathrm{R}$, and cytokine-producing cells were analyzed by intracellular cytokine staining. As shown in Supplemental Figure 2, the amount of IFN- $\gamma$ production (as measured by mean fluorescent intensity) on a per-cell basis was almost identical between WR- and Lister-infected groups over a wide range of peptide concentrations, similar to other assessments of IFN- $\gamma$ (Figure 2, C and D). This suggests that exposure to varying levels of viral antigen primarily affects the frequency of $\mathrm{CD}^{+} \mathrm{T}$ cells elicited rather than the functional activity of individual cells.
Furthermore, mice exposed to virus via the i.n. route (Figure 1B) also generated 2- to 5-fold fewer lung-resident memory CD8 ${ }^{+}$ $\mathrm{T}$ cells in response to WR-B18R, Lister, or $\mathrm{NYCBOH}$, even when 30 -fold more virus was inoculated (Figure 2B). This did not simply apply to the $\mathrm{B} 8 \mathrm{R}^{+}$population, but was observed when $\mathrm{CD}^{+}$ T cells were examined reactive with peptides of A3L, A8R, and B2R. Notably, 540 days after i.p. infection, the frequency of persisting memory VACV-reactive CD8 ${ }^{+} \mathrm{T}$ cells in both spleen and lung was 3to 10-fold greater in mice infected with WR compared with those infected with WR-B18R, Lister, or NYCBOH (Figure 2, C and D).

Analysis of the initial effector $\mathrm{CD}^{+} \mathrm{T}$ cell response showed that this difference was likely to be explained by altered molecular regulation during the primary infection, as the size of these populations of VACV-specific T cells correlated to an extent with the size of the memory $T$ cell pools and, again, opposite to the rate of virus clearance (Figure 2, E and F). Therefore, the immune system generates greater numbers of VACV-reactive memory $\mathrm{CD}^{+} \mathrm{T}$ cells with virus that replicates most extensively and is not rapidly cleared, consequently exposing the immune system to viral antigens for extended periods.

Selective use of $\mathrm{OX} 40$ to drive VACV-specific $C D 8^{+} T$ cells related to virulence. We then assessed whether the molecular control of $\mathrm{CD}^{+}$ effector and memory $\mathrm{T}$ cells elicited by the attenuated VACV strains paralleled that in response to WR. We recently demonstrated a major role for OX40/OX40L interactions in generating $\mathrm{CD}^{+} \mathrm{T}$ cell memory in response to WR (25) and therefore initially focused on these molecules. OX40 is not constitutively present on $\mathrm{T}$ cells, but has to be induced by antigen recognition and inflammatory stimuli; similarly, OX40L is only expressed on APCs such as dendritic cells and B cells after their activation by a variety of stimuli and cytokines $(18,26)$. Importantly, the absence of OX40 only impaired memory in response to WR, but did not affect the number of memory CD8 ${ }^{+} \mathrm{T}$ cells induced by WR-B18R, Lister, or $\mathrm{NYCBOH}$ (Figure 3, A and B). In fact, the magnitude of the CD8 response to WR in $\mathrm{O} 44^{-/-}$mice highly correlated with the response to WR-B18R, Lister, and NYCBOH in WT mice. Therefore, a large cytokine-competent, VACV-reactive memory $\mathrm{CD}^{+} \mathrm{T}$ cell pool only formed when OX40 became active in response to strongly replicating virus. Virus-specific memory T cells did form when OX40 was not brought into play, but their frequency was markedly reduced.

To again determine whether this related to initial priming events during the periods of active virus replication, the $\mathrm{CD}^{+}$ $\mathrm{T}$ cell response at day 7 was assessed. There were approximately $75 \%$ fewer primary $\mathrm{CD}^{+} \mathrm{B}^{2} \mathrm{R}^{+} \mathrm{T}$ cells induced in $\mathrm{O} \times 40^{-/-}$mice after WR infection. In contrast, little difference in priming of $\mathrm{CD}^{+} \mathrm{T}$ cells reactive with $\mathrm{B} 8 \mathrm{R}$ (or another peptide, A23R; data not shown) was observed in $O x 40^{-/-}$mice infected with WR-B18R, Lister, or NYCBOH (Figure 3C). To further show that the overall response and use of OX40 was related at least in part to the extent of attenuation and to viral load, mice were infected with 10 times as much virus (Figure $3 \mathrm{D}$ ). The $\mathrm{CD}^{+} \mathrm{T}$ cell response to WR-B18R was strongly increased, to levels similar to WR, when given at the lower dose; OX40 became relevant and accounted for the enhanced response. The requirement for OX40 observed with a higher inoculum of WR-B18R directly correlated with increased viral titers recovered from the spleen (Figure 3E). A similar trend was also seen with NYCBOH: a 10-fold higher infection dose resulted in slightly elevated $\mathrm{CD}^{+} \mathrm{T}$ cell responses, albeit not to the same extent as WR or WR-B18R, and much of the enhanced response was attributable to $\mathrm{OX} 40$. 
A

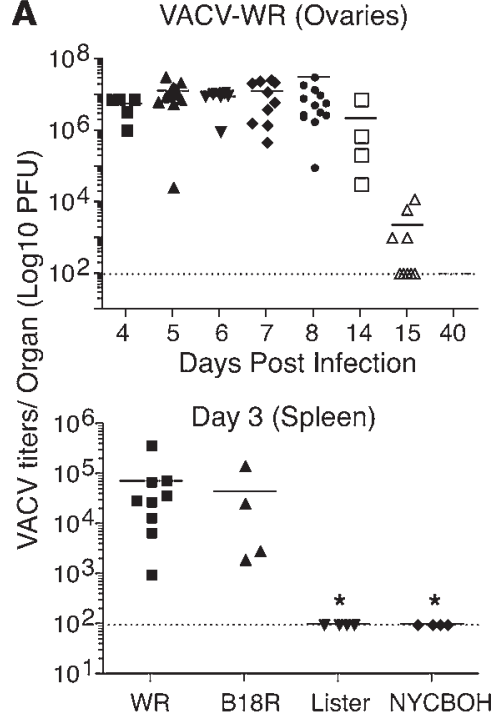

B

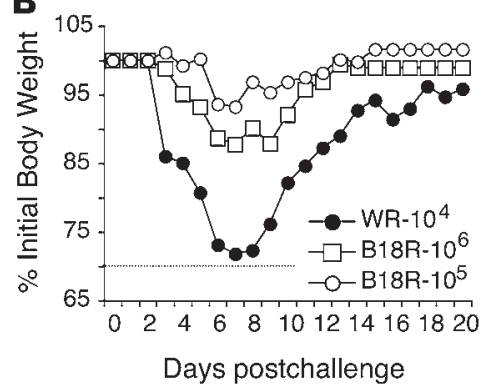

Day 5 (Ovaries)
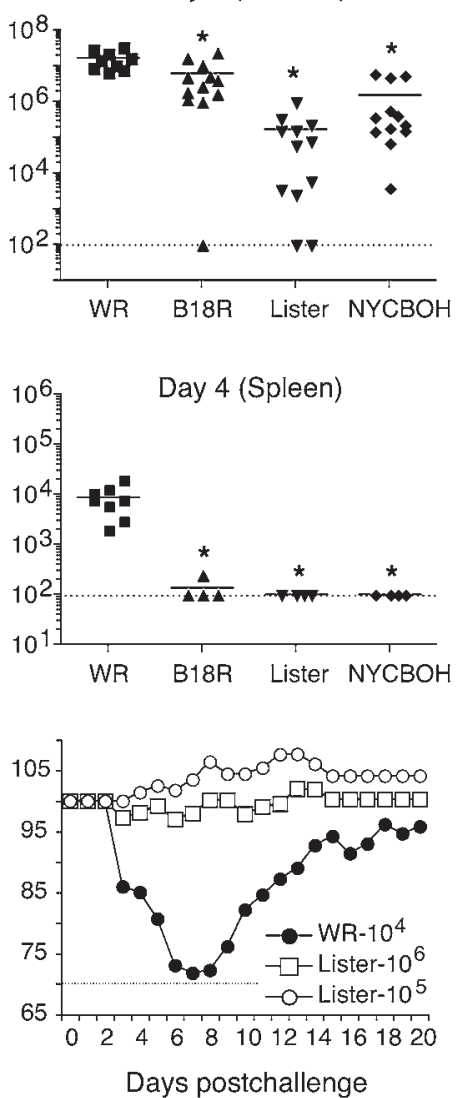

Day 7 (Ovaries)

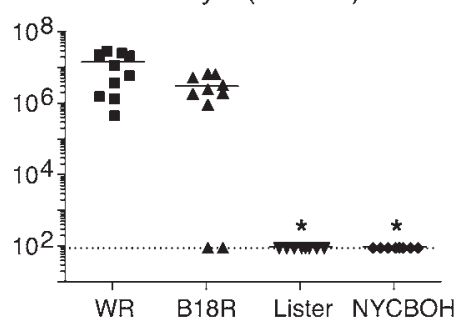

-i.p.
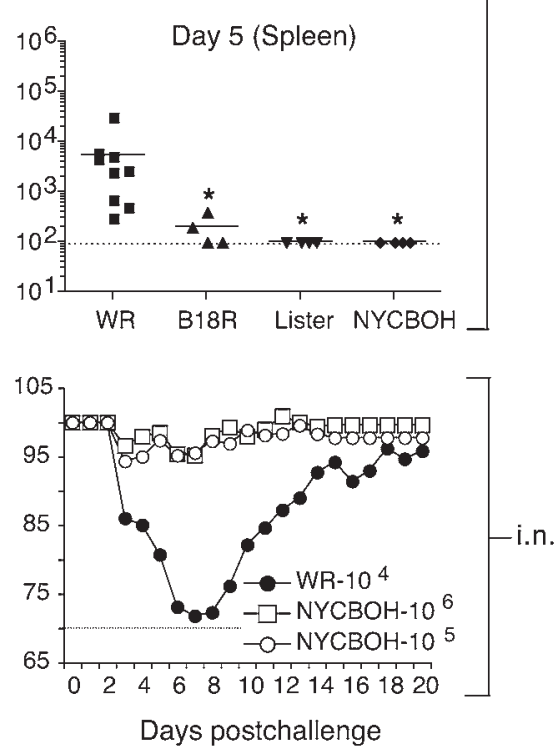

Figure 1

Altered virulence of VACV strains. C57BL/6 WT mice were infected i.p. with different strains of VACV $\left(2 \times 10^{5}\right.$ PFU). (A) On the indicated days after infection, ovaries and spleens were removed from individual mice, and VACV titers were determined as described in Methods. (B) WT mice were infected i.n. with $10^{4}$ PFU WR and $10^{5}$ or $10^{6}$ PFU WR-B18R, Lister, and NYCBOH as indicated. Animals were weighed daily. Mean percent of initial body weight is shown. Results are mean ( $n=4$ per group) from 1 of 3 experiments. ${ }^{*} P<0.05$ vs. WR.

To extend these findings, we injected poly:IC at the time of WR infection. Treatment with poly:IC is known to lead to elevated levels of cytokines like TNF and IFN-I that can suppress viral replication. Strikingly, poly:IC resulted in only low numbers of VACVreactive $\mathrm{CD}^{+} \mathrm{T}$ cells being generated, to levels approximating those induced in response to Lister and $\mathrm{NYCBOH}$ (Figure 3, F and $\mathrm{G})$. Most importantly, the weaker CD8 expansion seen with WR in the context of poly:IC injection directly correlated with reduced viral titers in the spleen (Figure $3 \mathrm{H}$ ), and this $\mathrm{T}$ cell response was independent of OX40. These data further show that the use of OX40 to drive enhanced $\mathrm{CD}^{+} \mathrm{T}$ cell priming and memory is related to the extent of viral load.

CD28 and CD27 are differentially active, depending on the stage of CD8 response and viral virulence. To determine whether this differential use of a stimulatory receptor applies to other, similar molecules, CD28 and CD27 were examined. CD28 is a costimulatory receptor in the Ig superfamily known to regulate initial activation of T cells in many immune responses in concert with antigen signals (27), and it has variably been reported to be required for $\mathrm{CD}^{+} \mathrm{T}$ cell responses against viruses (28). CD28 is constitutively expressed on T cells and binds B7.1 and B7.2 expressed on many APCs, and CD28-B7.2 interactions play a role in generating pools of VACVreactive $\mathrm{CD}^{+} \mathrm{T}$ cells after infection with $\operatorname{WR}(28,29)$. CD27 is another TNFR family member that acts independent of CD28 to promote $\mathrm{T}$ cell responses. CD27 is also constitutive on all T cells, but CD70, its ligand, is similar to OX40L and only induced once APCs such as dendritic cells or B cells receive certain inflammatory signals $(18,19)$. CD27/CD70 interactions were previously shown to be active in driving the $\mathrm{CD}^{+} \mathrm{T}$ cell response to WR (30). Furthermore, CD27 and OX40 have previously been shown to cooperate together to regulate $T$ cell memory to influenza virus $(31,32)$.

When memory was assessed 40 days after VACV i.p. infection, the requirement for CD27 followed the principles demonstrated for OX40: although CD27 contributed substantially to development of the high frequency of $\mathrm{CD}^{+} \mathrm{T}$ cells elicited to WR, it was not active in the weaker responses to Lister and $\mathrm{NYCBOH}$ (Figure $4 \mathrm{~A})$. This selective use of CD27 was again reflected in the primary effector response at day 8 , in that $\mathrm{CD} 27$ was not required for the smaller $\mathrm{CD}^{+} \mathrm{T}$ cell populations elicited in response to Lister or $\mathrm{NYCBOH}$, but controlled those induced in response to WR (Figure $4 \mathrm{~B})$. There was a small defect in the $\mathrm{CD} 8^{+} \mathrm{T}$ cell response in $\mathrm{Cd} 27^{-/-}$mice infected with the mutant WR-B18R virus, but again, the response in $\mathrm{Cd} 27^{-/-}$mice largely followed that in $\mathrm{O} \times 40^{-/-}$mice.

$\mathrm{Cd} 28^{-/-}$mice revealed a divergent pattern of usage. CD28 was required for development of primary $\mathrm{CD} 8^{+} \mathrm{T}$ cells induced to all virus variants when assessed at day 8 . In contrast, at day 40, CD28 
A

Day 40 (i.p.)

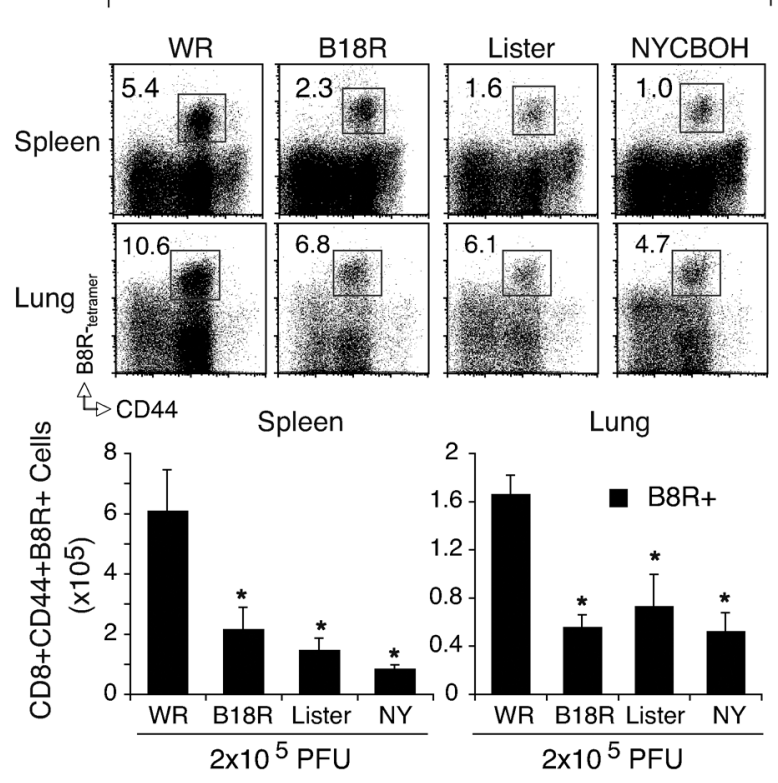

C

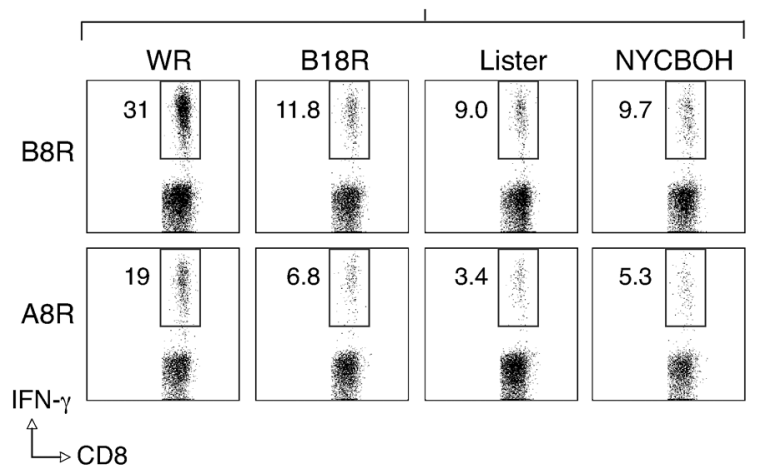

E

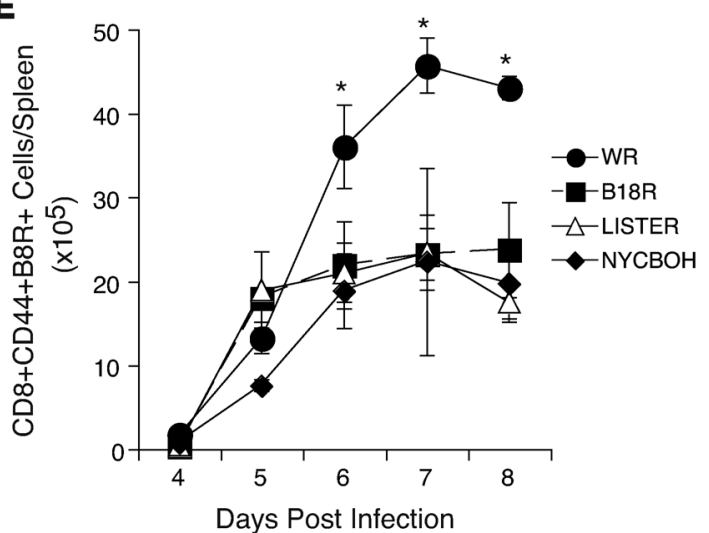

B

Day 60 (i.n.)

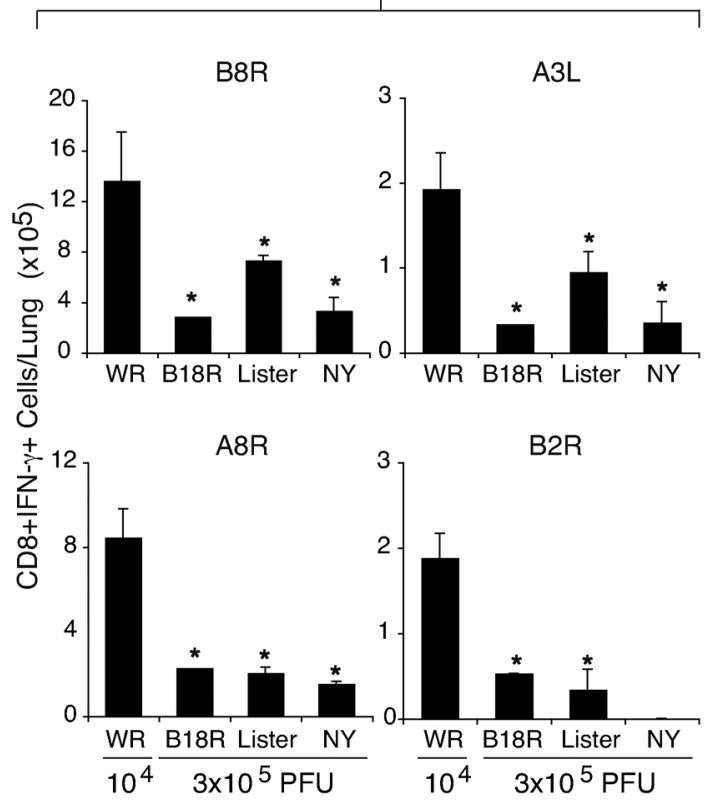

D

Day 540 (i.p.; Lung)

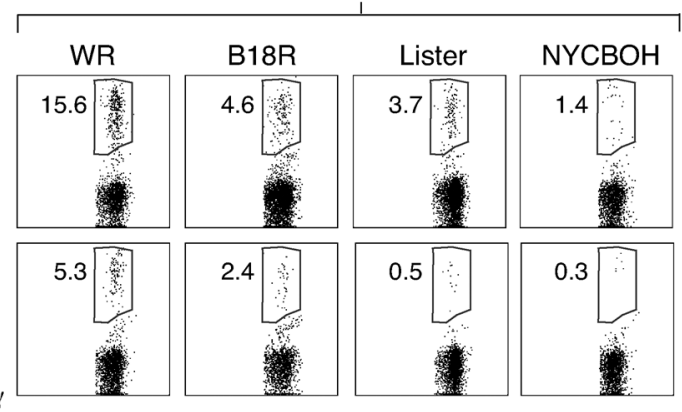

IFN- $\gamma$

$\longrightarrow$ CD8

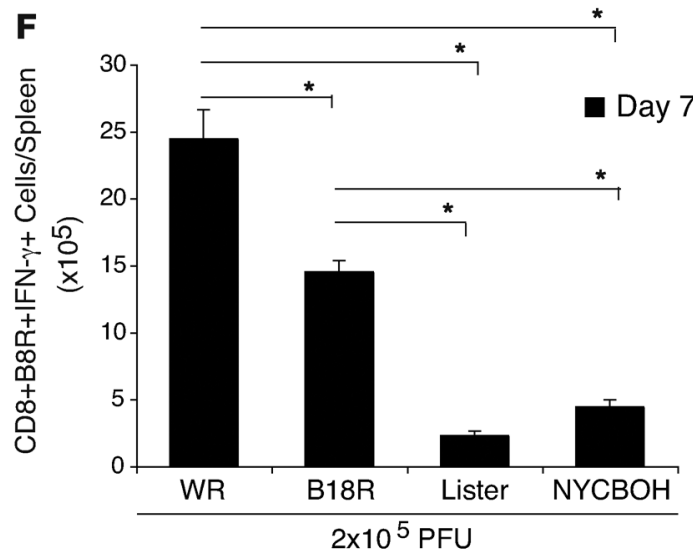

Figure 2

VACV virulence correlates with magnitude of $C D 8^{+}$T cell memory. WT mice were infected i.p. (A and $\left.\mathbf{C}-\mathbf{F}\right)$ or i.n. (B) with the indicated VACV strains. Splenocytes and lung cells were harvested on day 40 (A), day 60 (B), day 540 (C and D), or days 4, 5, 6, 7, and 8 (E and F) after infection and stained with anti-CD8, -CD44, and -B8R or for intracellular IFN- $\gamma$ after restimulation with the designated VACV peptides. (A) Representative plots of gated $C D 8^{+} T$ cells staining for $\mathrm{CD} 44$ and $B 8 R$ in spleen and lung. Numbers indicate percent $C D 44^{+} B 8 R^{+}$cells after gating on $C D 8^{+} T^{2}$ cells. Total numbers of $\mathrm{CD} 8^{+} \mathrm{CD} 44^{+} \mathrm{B} 8 \mathrm{R}^{+} \mathrm{T}$ cells per organ were determined as described in Methods. ${ }^{*} P<0.05$ vs. WR. (B) Number of CD8 ${ }^{+}$IFN- $\gamma^{+}$ T cells per lung specific for peptides B8R, A3L, A8R, and B2R. (C and D) Percent CD8+IFN- $\gamma^{+}$T cells per spleen (C) or lung (D) specific for B8R and A8R. ( $E$ and $\mathbf{F}$ ) Total number of $C D 8^{+} C D 44{ }^{+} B 8 R^{+}(E)$ and $C D 8{ }^{+} I F N-\gamma^{+}(F) T$ cells per spleen at the indicated time points after infection with VACV variants. Results are mean $\pm \operatorname{SEM}\left(n=4\right.$ per group) from 1 of 2 experiments. ${ }^{*} P<0.05$ vs. all other strains or as otherwise denoted. 

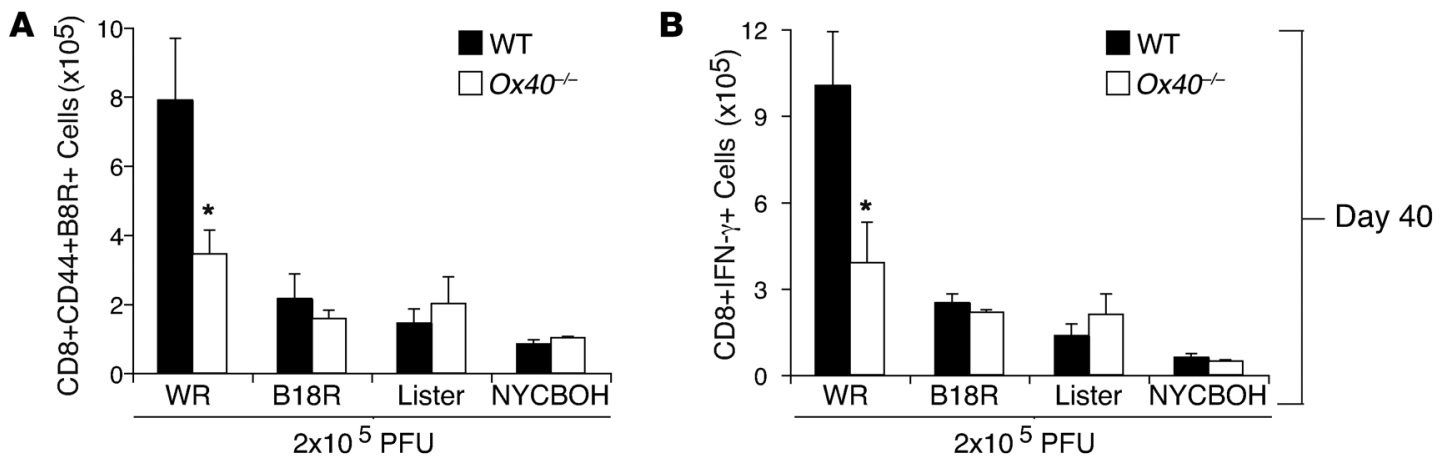

C

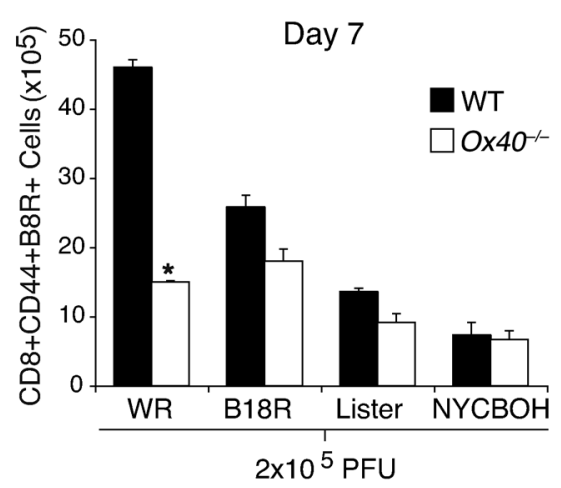

F
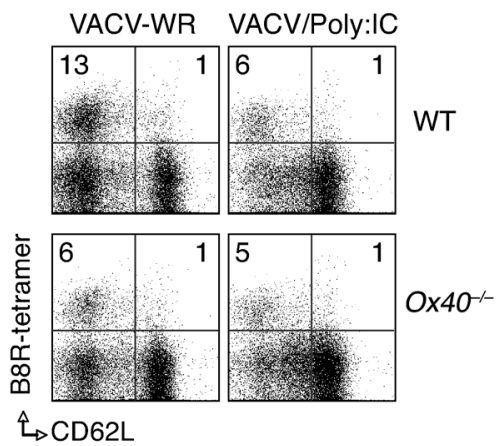

D

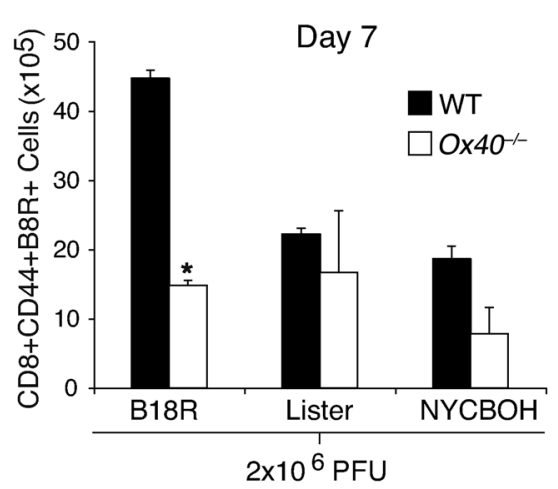

E

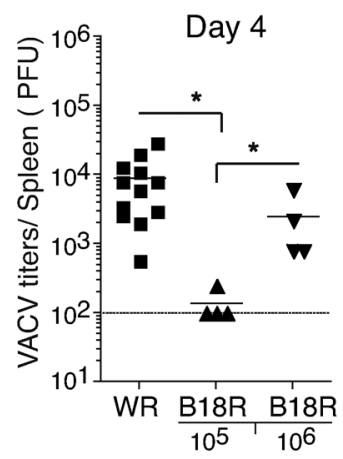

H

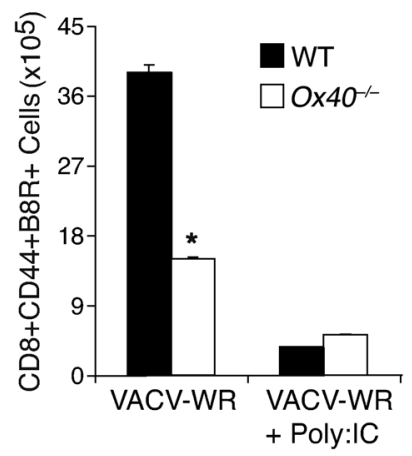

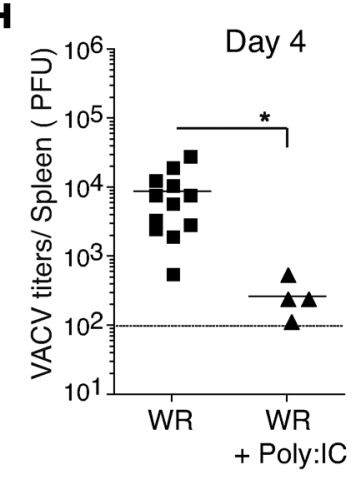

Figure 3

OX40 does not drive CD8 ${ }^{+} \mathrm{T}$ cell memory with attenuated viruses or when viral replication is low. (A-G) WT or Ox40-/- mice were infected i.p. with various VACV strains $\left(2 \times 10^{5}\right.$ or $\left.2 \times 10^{6} \mathrm{PFU}\right)$ as indicated. (H) At 1 day after infection with WR, mice were injected i.p. with $200 \mu \mathrm{g}$ poly: IC. At day 40 (A and B) or day 7 (C, D, F, and G), splenocytes were stained with CD8 plus CD44, CD62L, and B8R or intracellular IFN- $\gamma$, and the number of VACV-reactive CD8 ${ }^{+} \mathrm{T}$ cells was calculated. $(F)$ Representative plots of gated CD8 cells staining for CD62L and B8R in spleen. Numbers indicate percent CD62L+B8R ${ }^{+}$and CD62L-B8R ${ }^{+}$cells after gating on CD8 ${ }^{+} \mathrm{T}$ cells. Results are mean \pm SEM ( $n=6$ per group). ${ }^{*} P<0.05$ vs. WT. Similar results were obtained in 3 separate experiments. ( $E$ and $\mathbf{H}$ ) On day 4 after infection, spleens from the indicated groups were removed from individual mice, and VACV titers were determined as described in Methods. ${ }^{*} P<0.05$.

still contributed significantly to memory $\mathrm{CD}^{+} \mathrm{T}$ cell populations generated in response to WR-B18R, Lister, and NYCBOH, but memory $\mathrm{T}$ cell development in response to native WR was unaffected (Figure 4, A and B). The kinetics of development of VACV-reactive $\mathrm{CD}^{+} \mathrm{T}$ cells defined 2 obvious phases: a CD28-dependent phase, regulating primary effector cells, and a CD28-independent phase, beginning at day 12 , in which the frequency of $C D 8^{+} \mathrm{T}$ cells was equivalent in WT and Cd28-- mice (Figure 5, A and B). Further demonstrating that this CD28-independent memory generation was driven by the TNFR family molecules, blocking CD70 in $\mathrm{Cd} 28^{-/-}$ani- mals from day 5 after infection largely recapitulated the defect seen in the absence of CD27 (Figure 5, C and D). Thus, the strong T cell memory elicited in response to the virulent virus strain was dependent on 2 TNFR family interactions, whereas the weaker memory in response to Lister, NYCBOH, and WR-B18R strains was driven by CD28 and largely independent of the TNFR family molecules.

Immunization with WR, but not with $\mathrm{NYCBOH}$ or Lister, protects mice lacking MHC class II against lethal respiratory virus challenge. Next, this alternate use of costimulatory receptors that drove expanded memory was studied in terms of protection against subsequent viral 
A

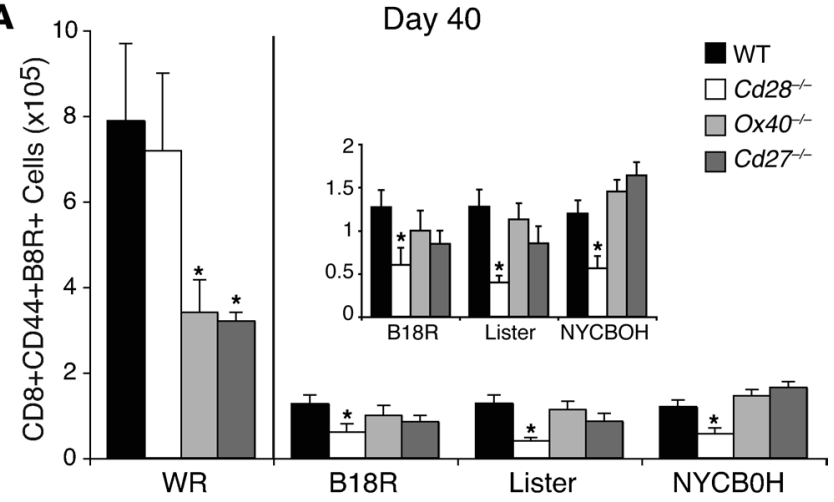

B

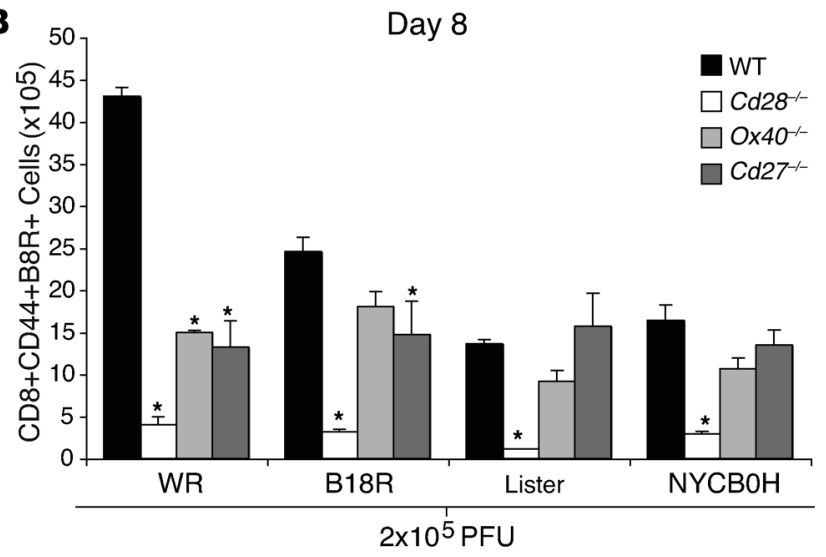

encounter. Because antibody can protect against VACV, we chose a model whereby $\mathrm{CD}^{+} \mathrm{T}$ cell activity can be separated from antibody-mediated protection. After i.n. infection with WR, naive mice exhibit weight loss and die within 6-9 days, but memory CD8 ${ }^{+}$ $\mathrm{T}$ cells induced by peptide vaccination can afford protection in this situation (25). MHC class II-deficient $\left(\mathrm{MHCII}^{-/}\right)$mice, which lack $\mathrm{CD}^{+} \mathrm{T}$ cells and cannot mount a VACV-specific neutralizing antibody response, were vaccinated with WR and Lister and challenged 70 days later with a lethal i.n. dose of WR. All mice vaccinated with WR survived the infection and exhibited only $10 \%-15 \%$ weight loss (Figure 6, A and B). Protection was dependent on $\mathrm{CD}^{+} \mathrm{T}$ cells, since their depletion before challenge resulted in $100 \%$ mortality. In contrast, no protection was evident in mice vaccinated with Lister or $\mathrm{NYCBOH}$, and all succumbed to the infection with kinetics similar to those of naive mice (Figure 6, A and B, and data not shown). This response paralleled the titers of virus detected in the lungs, which were strongly reduced (100- to 1,000-fold) in mice vaccinated with $\mathrm{WR}$, but not in those vaccinated with Lister (Figure $6 \mathrm{C}$ ). Consistent with the notion that the frequency of memory $\mathrm{T}$ cells dictated protection, far fewer B8R-specific memory CD8 ${ }^{+}$ $\mathrm{T}$ cells were present in the spleen and lungs of $\mathrm{MHCII}^{--}$mice after immunization with Lister (Figure 6, D and E). This shows that the $\mathrm{CD}^{+} \mathrm{T}$ cell memory elicited because of varying levels of replication, and the differential use of OX40 and CD27, correlated with the degree of protection that could subsequently be provided.

To formally demonstrate that the frequency of memory $\mathrm{CD}^{+}$ $\mathrm{T}$ cells is a primary determinant of the extent of protection afforded in the absence of $\mathrm{CD}^{+} \mathrm{T}$ cells and antibody, mice were infected with WR; 35 days later, varying numbers of naive $\left(\mathrm{CD} 8^{+} \mathrm{CD} 44^{\mathrm{lo}}\right)$ or VACV-reactive memory $\left(\mathrm{CD} 8{ }^{+} \mathrm{CD} 44^{\mathrm{hi}} \mathrm{B} 8 \mathrm{R}^{+}\right) \mathrm{T}$ cells were isolated

\section{Figure 4}

Virulence of VACV and stage of $\mathrm{CD}^{+} \mathrm{T}$ cell response determine the selective use of CD28, OX40, and CD27. WT, Cd28 $8^{-1}, \mathrm{O} \times 40^{-/-}$, or $\mathrm{Cd} 27^{-/-}$mice were infected i.p. with VACV variants $\left(2 \times 10^{5} \mathrm{PFU}\right)$ as indicated. At day $40(\mathbf{A})$ or day 7 (B), splenocytes were stained with CD8 plus CD44 and B8R, and the number of VACV-reactive CD8+ T cells was calculated. Results are mean \pm SEM ( $n=6$ per group). ${ }^{*} P<0.05$ vs. WT. Similar results were obtained in 2 separate experiments. Inset in A shows the same data for WR-B18R, Lister, and $\mathrm{NYCBOH}$ with the scale enlarged.

and then transferred directly into the lungs of naive recipients by intratracheal injection. As a positive control, infected mice were bled at the same time, and VACV-immune serum was prepared and transferred i.p. into separate groups of naive mice. All groups were subsequently infected i.n. with a lethal dose of WR. Mice that received naive $\mathrm{CD} 8^{+} \mathrm{T}$ cells did not survive the infection, whereas $100 \%$ were protected by direct intratracheal transfer of $1 \times 10^{4}$

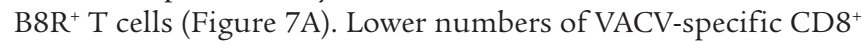
$\mathrm{T}$ cells either protected a fraction of mice or failed to protect at all, with the effect essentially proportional to the number of memory cells transferred. Similarly, the extent of disease as measured by weight loss directly correlated with the number of B8R-reactive memory $\mathrm{CD}^{+} \mathrm{T}$ cells transferred (Figure 7B).

Targeting $\mathrm{OX} 40$ enhances virus-specific $\mathrm{CD} 8^{+} T$ cell responses to attenuated VACVs. We further investigated whether engagement of OX40 would boost the response to an attenuated VACV strain by treating with an agonist antibody after infection. Anti-OX40 enhanced $\mathrm{CD}^{+} \mathrm{T}$ cell priming in response to Lister, with $300 \%-400 \%$ more tetramer- and IFN- $\gamma$-producing cells detected regardless of epitope specificity (Figure 8, A and B). To exclude the possibility that the enhanced VACV-specific CD8 ${ }^{+} \mathrm{T}$ cell response was dependent on $\mathrm{CD}^{+} \mathrm{T}$ cells, $\mathrm{MHCII}^{-1-}$ mice were infected with Lister. Anti-OX40 treatment again strongly enhanced the accumulation of these $\mathrm{CD}^{+} \mathrm{T}$ cells (Figure 8, C and D).

Most importantly, anti-OX40 provided complete protection against death in $\mathrm{MHCII}^{-/-}$mice vaccinated with Lister, which alone was ineffective at preventing lethality (Figure 8E). Notably, the extent of protection when mice were vaccinated with the combination of Lister and anti-OX40 was similar to that when mice were vaccinated with the virulent VACV strain WR. Thus, exogenous OX40 signals given at the time of activation of naive VACV-specific $\mathrm{CD}^{+} \mathrm{T}$ cells promote a large population of $\mathrm{CD}^{+}$ $\mathrm{T}$ cells that have the ability to fully protect against subsequent lethal virus infection.

WR and Lister scarification generates superior protective $C D 8^{+} T$ cell immunity against i.n. viral challenge that is mediated by CD28, OX40, and CD27. Finally, we addressed the findings of a recent study demonstrating that immunization with attenuated VACVs via skin scarification led to significantly higher levels of viral gene expression compared with other routes of immunization (33). Interestingly, this correlated with the development of greater numbers of IFN- $\gamma$-producing CD8 ${ }^{+} \mathrm{T}$ cells and the level of protection afforded against respiratory VACV challenge. To address whether this phenomenon relates to the use of OX40 and CD27 driving CD8 ${ }^{+} \mathrm{T}$ cell memory, we infected mice with WR and Lister by dermal scarification of the tail. Similar to the prior report (33), analysis of viral titers in the tail showed that in contrast to i.p. or i.n. Lister administration, very high levels of replication occurred, only moderately lower than that seen with WR, and Lister was not rapidly cleared 
A

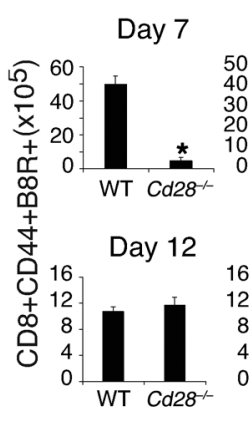

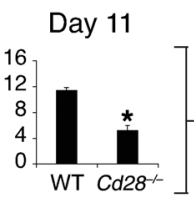

CD28 dependent phase Day 15

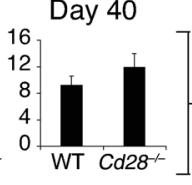

B

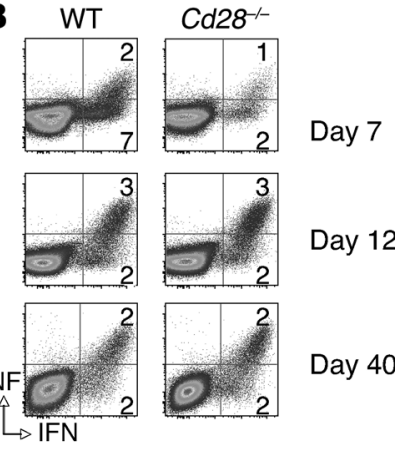

C

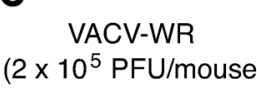

$\left(2 \times 10^{5} \mathrm{PFU} / \mathrm{mouse}\right)$

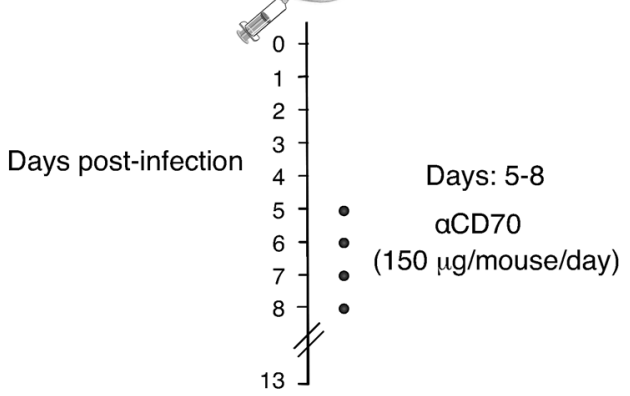

D
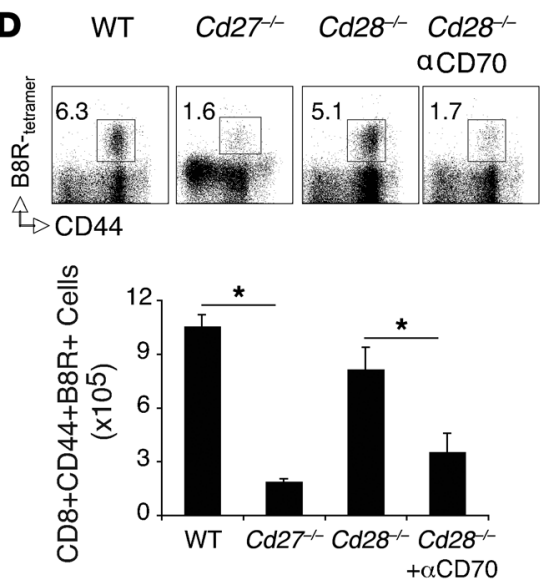

Figure 5

CD27 signaling is critical for CD28-independent $C D 8^{+} T$ cell responses to WR. (A and B) WT or $\mathrm{Cd} 28^{-/-}$mice were infected i.p. with WR $\left(2 \times 10^{5} \mathrm{PFU}\right)$. At the indicated days after infection, splenocytes were stained with CD8 plus CD44 and B8R (A), or intracellular IFN- $\gamma$ or TNF (B), and the number or percentage of VACV-reactive $C D 8^{+} T$ cells was calculated. (C and D) WT, Cd28Cd27-/- mice were infected i.p. with WR and injected i.p. on days 5, 6, 7, and 8 (C) with $150 \mu \mathrm{g}$ nondepleting antiCD70 blocking Ab in PBS. At day 13 after infection, splenocytes were harvested and stained for CD8, CD44, and B8R. (D) Representative plots of B8R staining, gating on $\mathrm{CD}^{+} T$ cells, as well as total number of $\mathrm{CD} 8^{+} \mathrm{CD} 44^{+} \mathrm{B} 8 \mathrm{R}^{+}$ $T$ cells per spleen. Numbers within dot plots denote percentage of cells in the respective quadrants/gates. Results are mean \pm SEM ( $n=4$ per group). ${ }^{\star} P<0.05$. Similar results were obtained in 2 separate experiments.
(Figure 9A). The CD8 ${ }^{+} \mathrm{T}$ cell response to both WR and Lister in WT mice was strongly increased compared with i.p. infection (compare Figure 9, B and C, with Figure 3C); specifically, scarification with Lister resulted in numbers of $\mathrm{CD} 8^{+} \mathrm{B} 8 \mathrm{R}^{+} \mathrm{IFN}-\gamma^{+} \mathrm{T}$ cells similar to those induced with i.p. WR (Figure 9, C and D). Most importantly, and correlating with our prior data and hypotheses, OX40 and CD27, as well as CD28, were then involved in driving this $\mathrm{CD}^{+} \mathrm{T}$ cell response to Lister (Figure 9, C and D). Immunization of $\mathrm{MHCII}^{-/-}$mice with Lister via scarification resulted in complete protection from death against i.n. VACV challenge (Figure 9E), again showing the relationship among viral replication, enhanced priming of $\mathrm{CD}^{+} \mathrm{T}$ cells, and use of these TNFR family costimulatory molecules.

\section{Discussion}

Recent animal and clinical studies have questioned whether attenuated poxvirus-based vectors that are currently under evaluation for vaccination elicit optimal long-lived $\mathrm{CD}^{+} \mathrm{T}$ cell immunity. For example, the ALVAC HIV-1 vaccine in humans elicited HIV-1-specific CD8 ${ }^{+} \mathrm{T}$ cell responses in less than $25 \%$ of normal volunteers (8-10). Similarly, MVA expressing the GAG protein (consensus of HIV-1 clade A) and several immunodominant $\mathrm{CD}^{+} \mathrm{T}$ cell epitopes resulted in responses detectable in only $17 \%$ of individuals (34). A smaller study using the same vaccines at a higher dose showed enhanced immunogenicity (40\% response), but the responses induced were exclusively the result of $\mathrm{CD}^{+} \mathrm{T}$ cells (7). As previously shown by Morgan et al. (17) and supported by our present data, the virulence of a VACV vector also critically influences the protective efficacy of the recombinant vaccine. Cottontop tamarins vaccinated with a
WR-based recombinant expressing the gp340 envelope antigen of Epstein-Barr virus were protected against Epstein-Barr virusinduced lymphoma, but animals inoculated with the NYCBOHbased recombinant, previously used as a smallpox vaccine, were not protected. Our present studies extend these previous reports by revealing that attenuated poxviruses may not elicit the best long-term $\mathrm{T}$ cell memory, because they did not allow molecules such as OX40 and CD27 to be engaged and be active. The virulence of VACV led to the selective and differential use of these $T$ cell costimulatory receptors, and this dictated the development of elevated frequencies of memory $\mathrm{CD}^{+} \mathrm{T}$ cells that are fully protective against a highly lethal virus challenge. This has significant implications for understanding mechanisms by which antiviral immunity is induced, and also for methodologies used to vaccinate individuals against pathogen attack. Increasing the number of primed $\mathrm{CD}^{+} \mathrm{T}$ cells by agonist engagement of OX40 improved the efficacy of vaccination with attenuated VACV, which suggests that future vaccine strategies should consider targeting OX40 or CD27 - and perhaps similar costimulatory molecules in the TNFR superfamily - to retain the ability to use attenuated poxvirus-based vaccines, but still promote all arms of the immune response. This could be done in humans with agonist antibodies, or trimeric or oligomeric Fc fusion proteins of the ligands for these molecules (OX40L and CD70, respectively). Alternatively, a TNF family ligand-expressing viral vector should also be extremely immunogenic, and may offer an alternative to monoclonal antibodies or fusion proteins.

Interestingly, results related to the inhibitory molecule PD-1 have shown that it also can be selectively used. PD-1 plays a limited role during infection with a virus that infects acutely, but it can 
A

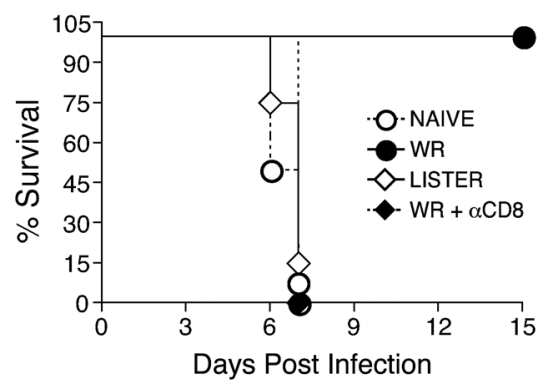

B

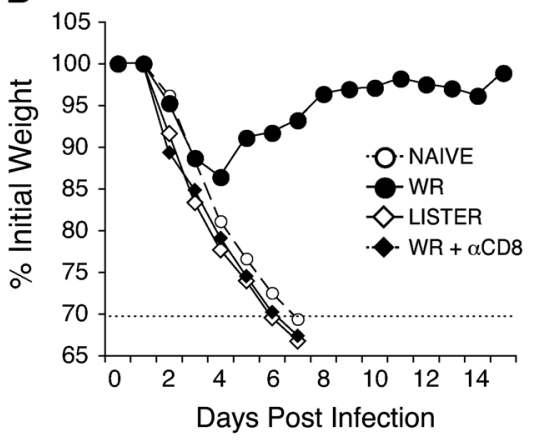

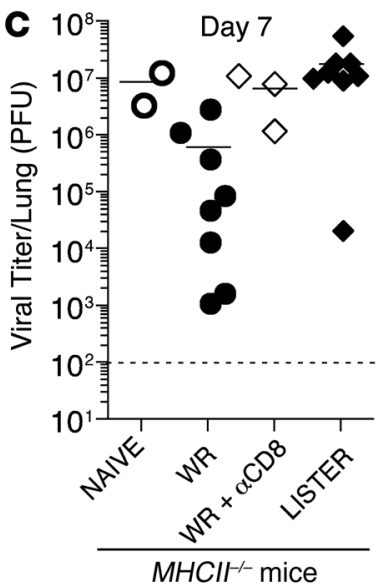

D

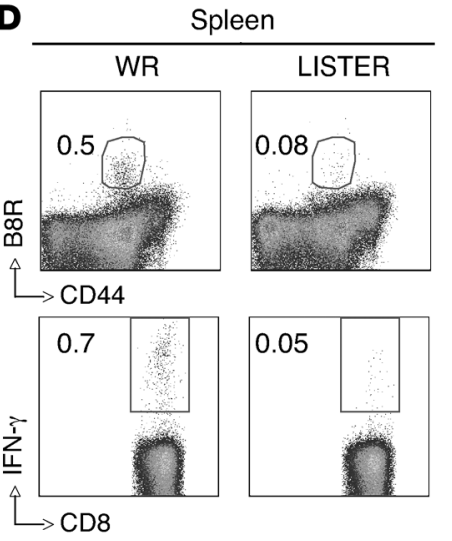

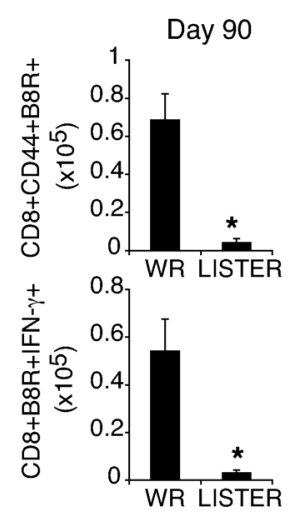

E

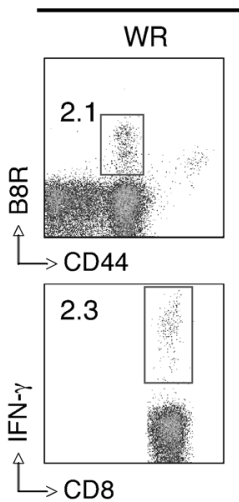

Lung
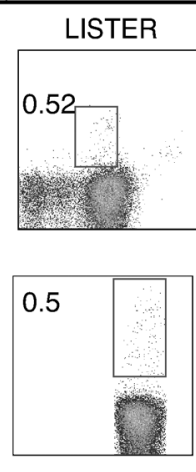

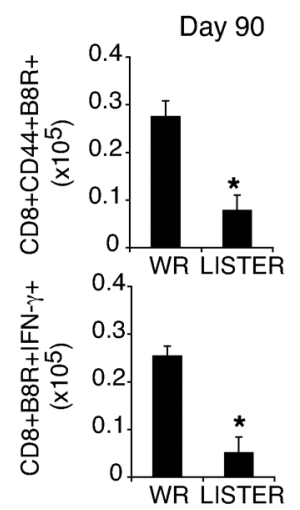

\section{Figure 6}

Vaccination of $\mathrm{MHCll}^{---}$mice with WR, but not $\mathrm{NYCBOH}$ or Lister, protects against lethal respiratory virus challenge. $\mathrm{MHCII^{-- }}$ mice were immunized i.p. with VACV variants $\left(2 \times 10^{5} \mathrm{PFU}\right)$. Naive $\mathrm{MHCII}^{--}$mice were used as control. 10 weeks after vaccination, mice were infected i.n. with a lethal dose of WR $\left(4.5 \times 10^{6} \mathrm{PFU}\right.$; i.e., $\left.400 \times \mathrm{LD}_{50}\right)$. Some $\mathrm{MHCl}^{--}$groups were depleted of $\mathrm{CD}^{+}(\alpha \mathrm{CD} 8) \mathrm{T}$ cells before i.n. challenge with VACV. Animals were weighed daily and euthanized if weight loss was greater than $30 \%$ body weight. Mean percent survival (A) and percent of initial body weight (B) are shown. Mean weight data in some cases were not plotted beyond the point at which mice died and beyond day 7 reflected only mice that survived infection. (C) On day 7 after challenge, tissues from individual mice that survived the infection were collected, and virus titers were determined by plaque assay as described in Methods. Results are mean ( $n=4$ per group) from 1 experiment. (D and E) Percent and total number of $\mathrm{CD} 8{ }^{+} \mathrm{CD} 44^{+} \mathrm{B} 8 \mathrm{R}^{+}$cells and B8R-reactive, IFN- $\gamma$-producing $\mathrm{CD}^{+}{ }^{+} \mathrm{CD} 6 \mathrm{~L}^{-}$cells in the spleen (D) and lungs $(\mathrm{E})$ of $\mathrm{MHCll^{-- }}$ mice 90 days after immunization with WR or Lister. Results are mean $\pm \operatorname{SEM}\left(n=4\right.$ per group) from 1 experiment. ${ }^{*} P<0.05$ vs. WR.

become highly active with certain strains of LCMV (35), and with HIV (36), that are persistent and infect chronically. PD-1 limits $\mathrm{CD}^{+} \mathrm{T}$ cell reactivity over extended periods, in this case in favor of the virus. Our data represent the opposite effect, in favor of the host. OX40 and CD27 did not participate in any substantial way in priming of $\mathrm{CD}^{+} \mathrm{T}$ cells against VACV strains that were rapidly cleared. Thus, OX40 and CD27 were not active when the immune system was very efficient in eliminating the primary infection.

Variable results in use, and timing of use, of OX40 and CD27 have been reported before in systems with other viruses, such as LCMV Armstrong, influenza virus, vesicular stomatitis virus (VSV), and MCMV; in some cases, these molecules played limited or no roles in primary $\mathrm{T}$ cell responses, strong roles in memory $\mathrm{T}$ cell generation, or were found essential for secondary reactivity of memory populations (30-32, 37-41). Similarly, reports of the dependency for CD28 signaling to generate virusspecific $\mathrm{CD}^{+} \mathrm{T}$ cells also diverge considerably. $\mathrm{Cd} 28^{-/-}$mice infected with LCMV generated a normal CD8 response $(42,43)$, but $\mathrm{CD}^{+} \mathrm{T}$ cell priming in response to VSV (44) and influenza $(41,45)$ was severely impaired. As proposed before $(19,31,32)$, some of this variability implied that the route of infection, the dose of virus used for infection, and whether the infection was acute or chronic might control the requirement for these individual interactions, perhaps reflecting differences related to the rate of viral replication, antigenic load, and the cytokine milieu induced in response to each virus. We now provide direct data in support of these hypotheses. The use and activity of OX40 and CD27 were characterized by the generation of a high frequency of long-lasting and functional memory $\mathrm{CD} 8^{+} \mathrm{T}$ cells, but only when replication was for extended periods or if the inoculum of virus used for infection was markedly increased (also translating to a greater viral load over time). This is particularly significant in that the memory $\mathrm{CD}^{+} \mathrm{T}$ cells induced had the ability to protect against future viral challenge in the absence of other mechanisms, including help from $\mathrm{CD}^{+} \mathrm{T}$ cells and neutralizing antibody, and this was directly proportional to their numbers. 
A

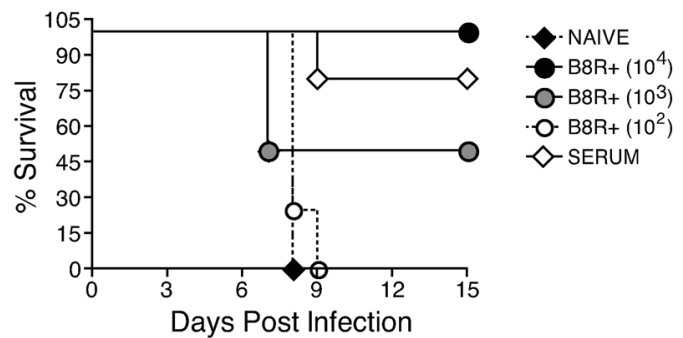

B

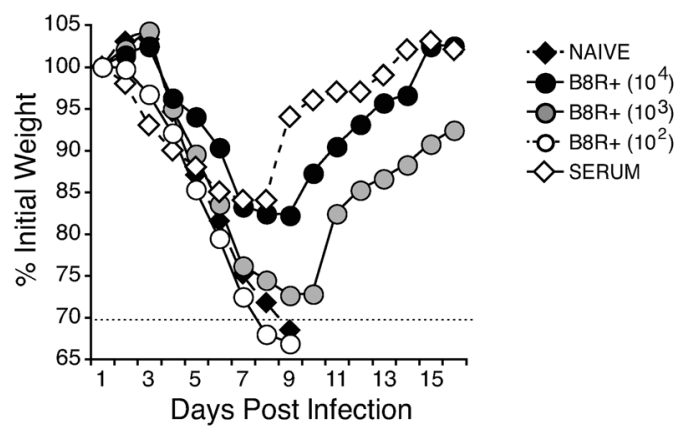

\section{Figure 7}

The frequency of $C D 8^{+} T$ cells in the lung prior to challenge directly correlates with the degree of protection against lethal VACV infection. Naive CD8+CD44lo and VACV-reactive memory CD8+CD44hi $88 \mathrm{R}^{+}$ $T$ cells were isolated from WR-infected mice, and varying numbers were instilled into the lungs of naive mice via the trachea. Some groups received $400 \mu$ l VACV-immune serum i.p. 1 day after transfer, mice were infected i.n. with a lethal dose of WR $\left(1 \times 10^{6} \mathrm{PFU}\right.$; i.e., $\left.100 \times \mathrm{LD}_{50}\right)$. Animals were weighed daily and euthanized if weight loss was greater than $30 \%$ body weight. Mean percent survival $(\mathbf{A})$ and percent of initial body weight (B) are shown. Mean weight data in some cases were not plotted beyond the point at which mice died and beyond day 7 reflected only mice that survived infection. Results are mean ( $n=4$ per group) from 1 experiment.
Although antiviral antibody can protect mice in the absence of $\mathrm{CD}^{+} \mathrm{T}$ cells $(4,46,47)$, mice deficient in B cells or MHC class II are dependent on $\mathrm{CD}^{+} \mathrm{T}$ cells in protecting against VACV (4, 48). Thus, this argues that the development of such high frequencies of protective memory $\mathrm{CD}^{+} \mathrm{T}$ cells will offset any deficiency in the antibody arm of the antiviral response.

Our data further highlight the importance of TNFR/TNF superfamily molecules in eliciting protective $\mathrm{T}$ cell memory. A group of these receptor-ligand pairs are inducible molecules on $\mathrm{T}$ cells and/or APCs, often appearing late in the response, typified by - although not exclusive to - the interactions of OX40 with OX40L, CD27 with CD70, TNFR with TNF, GITR with GITRL, CD30 with CD30L, 4-1BB with 4-1BBL, and HVEM with LIGHT $(18,19,32,49,50)$. The genes for these molecules are tightly clustered in groups on several human chromosomes and are thought to have arisen through duplication and genome expansion, with their products arguably possessing similar intrinsic functional activity. Over the years, we and others have proposed models whereby such costimulatory molecules act together at any one time to allow for both quantitative and qualitative control of $\mathrm{T}$ cells, as well as acting at different times in a temporal sequence $(18,19,31,49,50)$. It has been hypothesized that the immune system might need this type of cooperative action because of natural or induced suppressive activities that limit immune reactivity. Certainly, there are many suppressive or coinhibitory receptorligand pairs, including PD-1 and its ligands, that directly oppose costimulatory interactions. Thus, molecules such as OX40 and OX40L, CD27 and CD70, and their related family members might have arisen to allow maximal immune flexibility, to ensure effective development of protective immunity against pathogens, and to overcome suppressive influences from preexisting inhibitory receptors. Alternatively, the inhibitory receptors might have evolved to limit the activity of the multitude of stimulatory receptors and prevent excessive immune-mediated pathology and limit autoreactivity. Regardless of which came first, an attractive idea is that the evolution of this extremely complex system of receptorligand interactions was in part in response to virulence mechanisms and the extent of pathogen replication.
In summary, we provide insight into the development of $\mathrm{CD}^{+}$ $T$ cell immunity to a virus and show that virulence and the extent of viral replication can lead to differential use of costimulatory receptors for T cells. We demonstrate that molecular plasticity can occur during antiviral responses, in which certain immune mechanisms thought nonessential could become highly relevant, and provide insights into factors that may allow for better vaccine design.

\section{Methods}

Mice. The studies reported here conform to the animal Welfare Act and the NIH guidelines for the care and use of animals in biomedical research. All experiments were done in compliance with the regulations of the La Jolla Institute Animal care committee in accordance with the guidelines by the Association for Assessment and Accreditation of Laboratory Animal Care. Female $\mathrm{C} 57 \mathrm{BL} / 6$ mice and $\mathrm{Cd} 28^{-/-}$and $\mathrm{MHCII^{-- }}$ mice on the $\mathrm{C} 57 \mathrm{BL} / 6$ background (8-12 weeks old) were purchased from The Jackson Laboratory. Ox40-/and $C d 27^{-/-}$mice (40) on the C57BL/6 background were bred in house.

Peptides and tetramers. VACV peptide epitopes used in this study were predicted and synthesized as described previously $(23,24,28)$. The aa sequences for the peptides used were as follows: B8R (aa 20-27; TSYKFESV), A3L (aa 270-227; KSYNYMLL), A8R (aa 189-196; ITYRFYLI), B2R (aa 54-62; YSQVNKRYI), A23R (aa 297-305; IGMFNLTFI). MHC/peptide tetramers for the WR epitope B8R (20-27; TSYKFESV)/H-2K ${ }^{\mathrm{b}}$, which were conjugated to allophycocyanin, were obtained from the NIH Tetramer Core facility at Emory University.

Viruses. The WR and Lister VACV strains were purchased from the American Type Culture Collection, grown in HeLa cells, and titered on VeroE6 cells. NYCBOH was generated as low-passage stocks from commercial Dryvax (Wyeth) and grown using the same conditions described for WR. The construction and characterization of recombinant WR-B18R deletion mutant was as described previously (51).

Immunization protocols. For most experiments, mice were infected i.p. with $2 \times 10^{5} \mathrm{PFU}$ VACV. Effector responses were analyzed between days 7 and 8 after infection, while memory responses were analyzed 30 or more days after infection, after restimulating in vitro with VACV peptides as described previously (52). For dermal scarification, virus $(10 \mu \mathrm{l})$ was deposited at the base of the tail, and the skin at the site of the droplet was scarified 25-30 times with a 25-gauge needle. After 3-4 days, pustules or scabs were observed at the scarification site, indicating a localized VACV infection. 
A

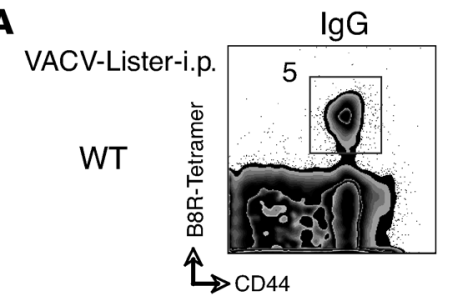

$\alpha \mathrm{OX} 40$

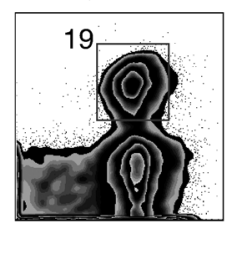

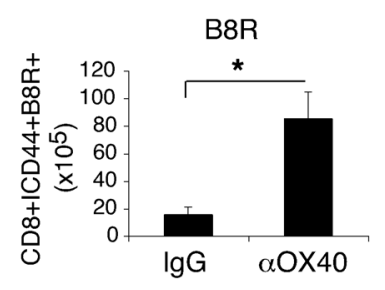

B

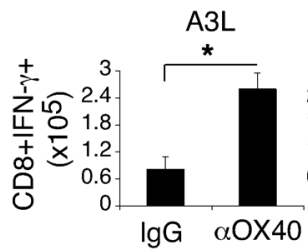

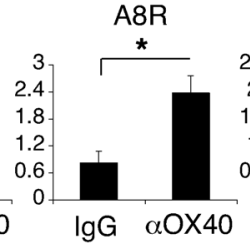

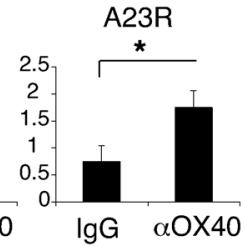

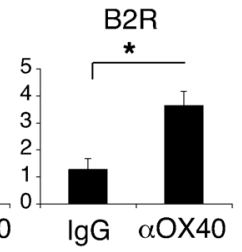

C

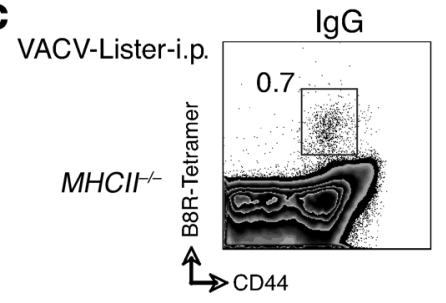

$\alpha \mathrm{OX} 40$

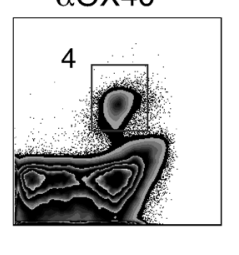

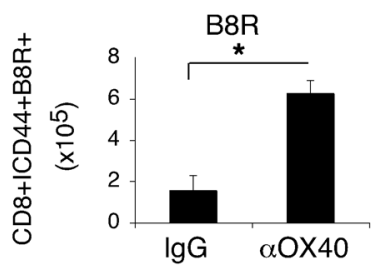

D

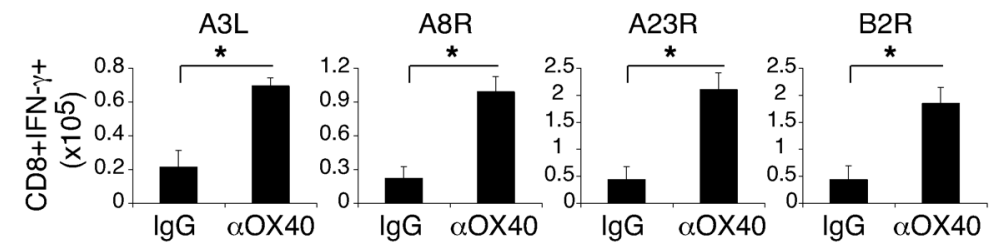

E

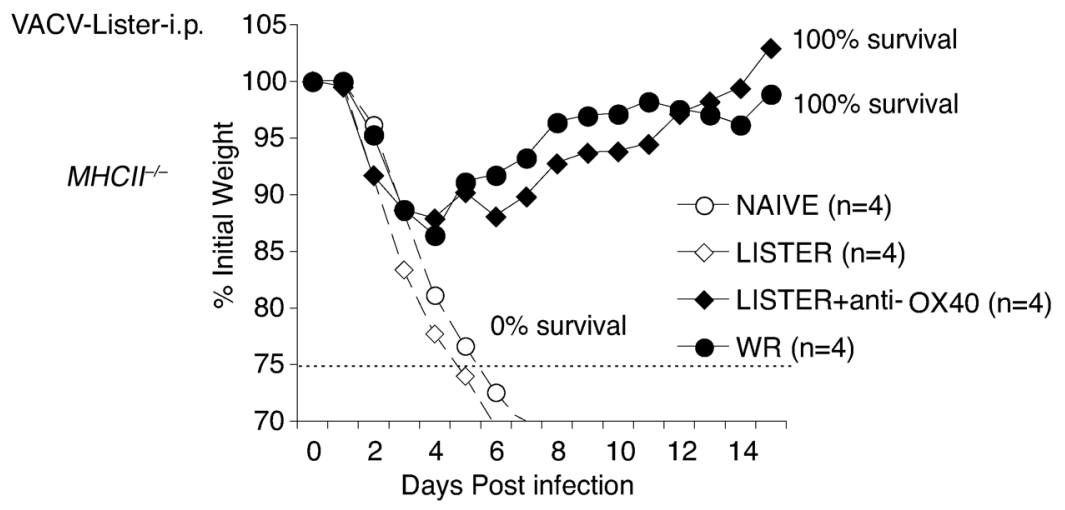

Figure 8

Enhanced $C D 8^{+} T$ cell responses to attenuated VACVs following agonist anti-OX40 treatment. WT (A and $\mathbf{B}$ ) and $\mathrm{MHCll}^{-1-}$ (C-E) mice were infected with $2 \times 10^{5}$ PFU Lister i.p. 1 day later, mice were treated with $150 \mu \mathrm{g}$ control rat IgG or anti-OX40 ( $\alpha \mathrm{OX} 40) .8$ days after infection, VACV-specific CD8 ${ }^{+} T$ cells were assessed by tetramer (A and $\mathbf{C}$ ) or by intracellular IFN- $\gamma$ staining after stimulation with the indicated VACV peptides (B and $\mathbf{D})$. Data are either representative plots of tetramer staining in gated CD8 ${ }^{+} \mathrm{T}$ cells, with percent positive indicated, or total number (mean $\pm \mathrm{SEM}$ ) of $\mathrm{CD} 8^{+} \mathrm{IFN}-\gamma^{+} \mathrm{T}$ cells per spleen from 4 individual mice. ${ }^{*} P<0.05$. Similar results were obtained in 2 separate experiments. (E) $\mathrm{MHCII--}^{-1}$ mice were immunized i.p. with WR or Lister $\left(2 \times 10^{5} \mathrm{PFU}\right) .1$ day later, cohorts of Listerimmunized mice were treated with $150 \mu \mathrm{g}$ antiOX40. Naive $\mathrm{MHCll}^{--}$mice were used as control. 10 weeks after vaccination, mice were infected i.n. with a lethal dose of WR $\left(4.5 \times 10^{6} \mathrm{PFU}\right.$; i.e., $\left.400 \times \mathrm{LD}_{50}\right)$. Animals were weighed daily and euthanized if weight loss was greater than $25 \%$ body weight. Mean percent of initial body weight is shown, with percent survival indicated.

VACV i.n. challenge. Mice were anesthetized by inhalation of isoflurane and inoculated i.n. with $1 \times 10^{6}$ or $4.5 \times 10^{6} \mathrm{PFU}$ WR as indicated. Mice were weighed daily for 2 weeks following challenge and were euthanized when they lost $25 \%-30 \%$ of their initial body weight. For protection experiments, mice were immunized i.p. or via dermal scarification at the base of the tail with $2 \times 10^{5} \mathrm{PFU}$ WR, Lister, or NYCBOH. Body weight was calculated as percentage of the mean weight for each group on the day of challenge.

Flow cytometry. After lysing rbcs, splenocytes from infected mice were resuspended in RPMI-1640 medium (Invitrogen) supplemented with 10\% FCS (Omega Scientific), 1\% L-glutamine (Invitrogen), $100 \mu \mathrm{g} / \mathrm{ml}$ streptomycin, $100 \mathrm{U} / \mathrm{ml}$ penicillin, and $50 \mu \mathrm{M} 2$-mercaptoethanol (Sigma-Aldrich). $1-2 \times 10^{6}$ cells were plated in round-bottomed 96-well microtiter plates in $200 \mu \mathrm{l}$ with medium or the indicated VACV peptides at $1 \mu \mathrm{g} / \mathrm{ml}$ for 1 hour at $37^{\circ} \mathrm{C}$. GolgiPlug (BD Biosciences) was then added to the cultures according to the man-

Generation and adoptive transfer of VACV-reactive memory $C D 8^{+} T$ cells. WT mice were infected i.p. with $2 \times 10^{5} \mathrm{PFU}$ WR. At 40 days after infection, spleen cells were pooled, and $\mathrm{CD}^{+} \mathrm{T}$ cells were enriched by positive selection using Miltenyi microbeads per the manufacturer's instructions (Miltenyi Biotec) and subsequently sorted into different subsets based on naive $\left(\mathrm{CD}^{+}{ }^{+} \mathrm{CD} 44^{\mathrm{lo}}\right)$ and VACV-reactive memory $\left(\mathrm{CD} 8{ }^{+} \mathrm{CD} 44^{\text {hi }} \mathrm{B} 8 \mathrm{R}^{+}\right)$ expression by FACS. The purity of $\mathrm{CD}^{+} \mathrm{T}$ cells was confirmed to be greater than $99 \%$ by FACS analysis. For adoptive transfer experiments, varying numbers of naive and VACV-reactive memory $\mathrm{CD}^{+} \mathrm{T}$ cells $\left(1 \times 10^{4}, 1 \times 10^{3}\right.$, and $\left.1 \times 10^{2}\right)$ were instilled into the lungs via the trachea using a $1-\mathrm{ml}$ syringe fitted with a blunted $20-\mathrm{G}$ needle. 1 day later, mice were infected i.n. with a lethal dose of WR. ufacturer's instructions, and the incubation continued for 7 hours. Cells were stained with anti-CD8 (PerCP) and CD62L (PE), followed by fixation with cytofix/cytoperm (BD Biosciences) for 20 minutes at $4^{\circ} \mathrm{C}$. Fixed cells were subjected to intracellular cytokine staining in $\mathrm{BD}$ Perm/Wash buffer for 30 minutes at $4{ }^{\circ} \mathrm{C}$. Anti-TNF (FITC) and IFN- $\gamma$ (allophycocyanin) were obtained from eBiosience and used at 1:100 dilution. Samples were analyzed for their proportion of cytoplasmic cytokines after gating on CD8 ${ }^{+} \mathrm{CD} 62 \mathrm{~L}^{\text {lo }} \mathrm{T}$ cells by FACSCalibur flow cytometer using CellQuest (BD Biosciences) and FlowJo software (Tree Star).

$V A C V$ titer assay. After i.p. infection, tissues (lungs, spleens, and ovaries) from individual mice were homogenized and sonicated for 0.5 minutes with a pause every 10 seconds using an ultrasonic cleaner 
A

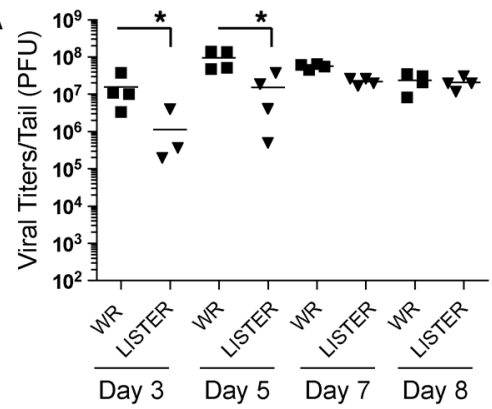

B
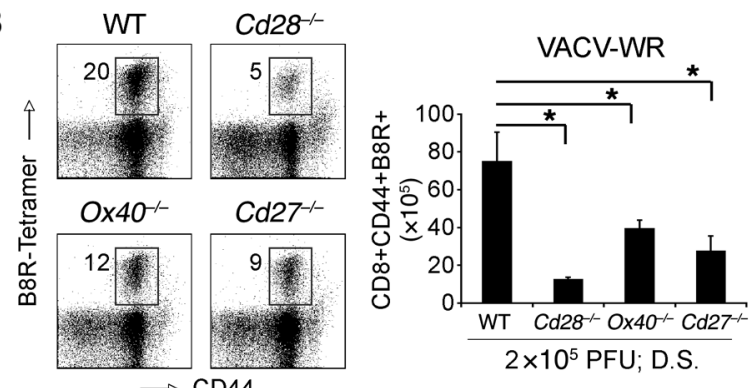

C
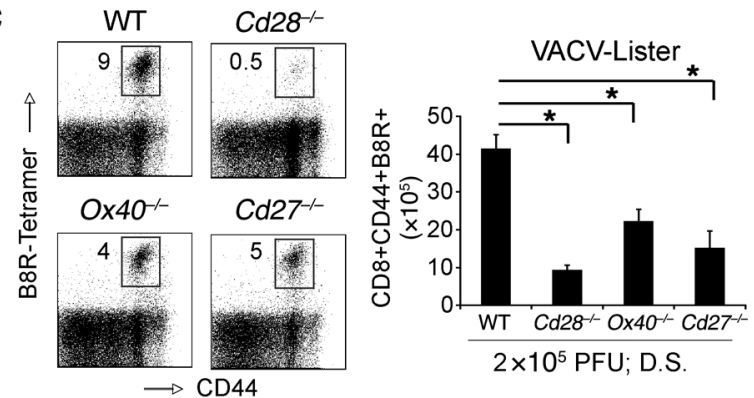

D

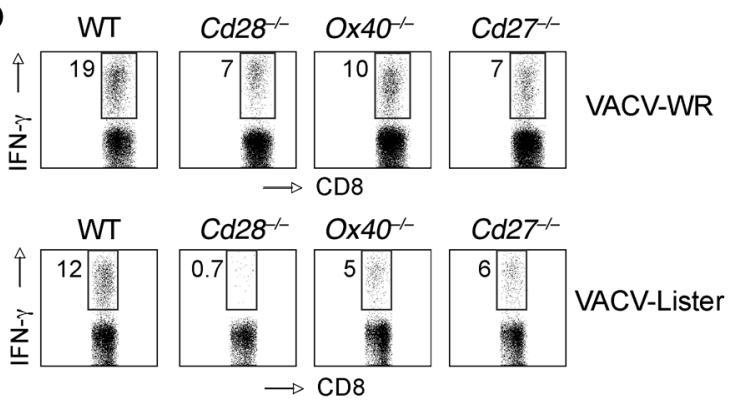

$\mathbf{E}$

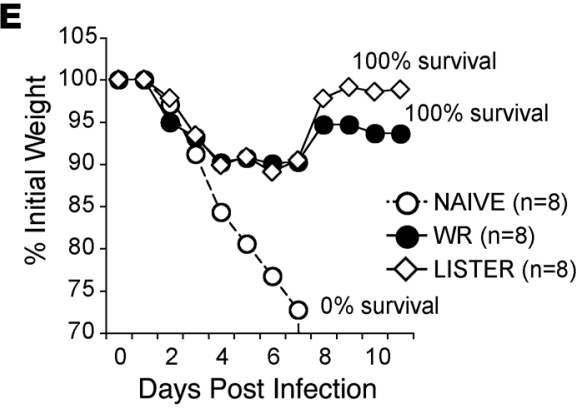

Figure 9

WR and Lister scarification generates superior protective CD8 ${ }^{+} \mathrm{T}$ cell immunity against i.n. viral challenge that is mediated by CD28, OX40, and CD27. WT mice were infected by dermal scarification with WR and Lister ( $2 \times 10^{5}$ PFU). (A) On the indicated days after infection, VACV titers at the site of infection were determined as described in Methods. ${ }^{*} P<0.05$. (B-D) 8 days after infection, splenocytes were harvested and stained with anti-CD8, -CD44, and -B8R or for intracellular IFN- $\gamma$ after restimulation with B8R peptide. (B and C) Representative plots of gated CD8 cells staining for CD44 and B8R in spleen. Numbers indicate percent CD44+B8R+ cells after gating on CD8+ ${ }^{+}$cells. Total number of CD8+CD44+B8R+ $\mathrm{T}$ cells per organ was determined as described in Methods. (D) Percent CD8+IFN- $\gamma^{+} \mathrm{T}$ cells per spleen specific for B8R peptide. Results are mean \pm SEM ( $n=4$ per group) from 1 of 3 experiments. ${ }^{*} P<0.05$. (E) $M H C l l^{-1-}$ mice were immunized by dermal scarification with WR and Lister $\left(2 \times 10^{5} \mathrm{PFU}\right)$. Naive $\mathrm{MHCII}^{-/}$mice were used as control. 10 weeks after vaccination, mice were infected i.n. with a lethal dose of WR $\left(4.5 \times 10^{6}\right.$ PFU; i.e., $400 \times \mathrm{LD}_{50}$ ). Animals were weighed daily and euthanized if weight loss was greater than $30 \%$ body weight. Mean weight data in some cases were not plotted beyond the point at which mice died and beyond day 7 reflected only mice that survived infection.

(1210 Branson). Serial dilutions were made, and virus titers were determined by plaque assay on confluent VeroE6 cells. For dermal scarification, the tail was cut at both sides of the scarification site. The excised tail was then homogenized and assessed for viral titers as described for spleens and ovaries.

In vivo $C D 8^{+} T$ cell depletion. Hybridomas were cultured in protein-free hybridoma medium-II (Invitrogen), and mAbs were isolated by dialysis of supernatant. Groups of WR-immunized $\mathrm{MHCII}^{-/-}$mice (deficient in MHC class II) were depleted of CD8 ${ }^{+} \mathrm{T}$ cells with anti-CD8 (clone 2.43; $200 \mu \mathrm{g} /$ mouse) given in 1 i.v. injection 3 days before, and 2 i.p. injections on days 1 and 4 after, i.n. challenge with WR. CD8 depletion was confirmed by flow cytometry of spleens and lungs of treated mice.

Avidity titration. Groups of WT mice were infected i.p. with $2 \times 10^{5} \mathrm{PFU}$
WR or Lister. 40 days after infection with VACVs, the avidities of $\mathrm{CD}^{+} \mathrm{B}^{\mathrm{B}} \mathrm{R}^{+}$ $\mathrm{T}$ cells were titrated by IFN- $\gamma$ intracellular staining after stimulation of splenocytes with graded concentrations of B8R peptide. Functional avidity was measured as the concentration of the peptide yielding $50 \%$ of the maximal response $\left(\mathrm{SD}_{50}\right)$.

Statistics. Statistical significance was analyzed by 1 -tailed Student's $t$ test. Unless otherwise indicated, data represent mean \pm SEM, with a $P$ value less than 0.05 considered statistically significant.

\section{Acknowledgments}

This work was supported by NIH grants CA91837 and AI67341 to M. Croft, by NIH grant AI77079 to S. Salek-Ardakani, and by a fellowship from the Center for Infectious Disease at the La Jolla Institute 
for Allergy and Immunology to S. Salek-Ardakani. This is publication no. 1211 from the La Jolla Institute for Allergy and Immunology.

Received for publication August 18, 2010, and accepted in revised form October 13, 2010.

1. Lee MS, et al. Molecular attenuation of vaccinia virus: mutant generation and animal characterization. JVirol. 1992;66(5):2617-2630.

2. Midgley CM, Putz MM, Weber JN, Smith GL. Vaccinia virus strain NYVAC induces substantially lower and qualitatively different human antibody responses compared with strains Lister and Dryvax. J Gen Virol. 2008;89(pt 12):2992-2997.

3. Frey SE, et al. Dose-related effects of smallpox vaccine. NEngl J Med. 2002;346(17):1275-1280.

4. Wyatt LS, Earl PL, Eller LA, Moss B. Highly attenuated smallpox vaccine protects mice with and without immune deficiencies against pathogenic vaccinia virus challenge. Proc Natl Acad Sci U S A. 2004;101(13):4590-4595.

5. Stittelaar KJ, et al. Safety of modified vaccinia virus Ankara (MVA) in immune-suppressed macaques. Vaccine. 2001;19(27):3700-3709.

6. Earl PL, et al. Immunogenicity of a highly attenuated MVA smallpox vaccine and protection against monkeypox. Nature. 2004;428(6979):182-185.

7. Peters BS, et al. Studies of a prophylactic HIV-1 vaccine candidate based on modified vaccinia virus Ankara (MVA) with and without DNA priming: effects of dosage and route on safety and immunogenicity. Vaccine. 2007;25(11):2120-2127.

8. Cleghorn F, et al. Lessons from a multisite international trial in the Caribbean and South America of an HIV-1 Canarypox vaccine (ALVAC-HIV vCP1452) with or without boosting with MN rgp120.J Acquir Immune Defic Syndr. 2007;46(2):222-230.

9. Goepfert PA, et al. High-dose recombinant Canarypox vaccine expressing HIV-1 protein, in seronegative human subjects. J Infect Dis. 2005;192(7):1249-1259.

10. Thongcharoen $\mathrm{P}$, et al. A phase $1 / 2$ comparative vaccine trial of the safety and immunogenicity of a CRF01_AE (subtype E) candidate vaccine: ALVACHIV (vCP1521) prime with oligomeric gp160 (92TH023/LAI-DID) or bivalent gp120 (CM235/SF2) boost. J Acquir Immune Defic Syndr. 2007;46(1):48-55.

11. Perkus ME, Tartaglia J, Paoletti E. Poxvirus-based vaccine candidates for cancer, AIDS, and other infectious diseases. J Leukoc Biol. 1995;58(1):1-13.

12. Gomez CE, Najera JL, Krupa M, Esteban M. The poxvirus vectors MVA and NYVAC as gene delivery systems for vaccination against infectious diseases and cancer. Curr Gene Ther. 2008;8(2):97-120.

13. Artenstein AW. New generation smallpox vaccines: a review of preclinical and clinical data. Rev Med Virol. 2008;18(4):217-231.

14. Meyer H, Sutter G, Mayr A. Mapping of deletions in the genome of the highly attenuated vaccinia virus MVA and their influence on virulence. J Gen Virol. 1991;72(pt 5):1031-1038.

15. Karem KL, et al. Monkeypox-induced immunity and failure of childhood smallpox vaccination to provide complete protection. Clin Vaccine Immunol. 2007;14(10):1318-1327.

16. Ferrier-Rembert A, Drillien R, Tournier JN, Garin $\mathrm{D}$, Crance JM. Short- and long-term immunogenicity and protection induced by non-replicating smallpox vaccine candidates in mice and comparison with the traditional 1 st generation vaccine. Vaccine. 2008;26(14):1794-1804.

17. Morgan AJ, Finerty S, Lovgren K, Scullion FT, Morein B. Prevention of Epstein-Barr (EB) virusinduced lymphoma in cottontop tamarins by vaccination with the EB virus envelope glycoprotein
Address correspondence to: Shahram Salek-Ardakani or Michael Croft, La Jolla Institute for Allergy and Immunology, Division of Molecular Immunology, 9420 Athena Circle, La Jolla, California 92037, USA. Phone: 858.752.6752; Fax: 858.752.6985; E-mail: ssalek@liai.org (S. Salek-Ardakani); mick@liai.org (M. Croft). gp340 incorporated into immune-stimulating complexes. J Gen Virol. 1988;69(pt 8):2093-2096.

18. Croft M. The role of TNF superfamily members in T-cell function and diseases. Nat Rev Immunol. 2009;9(4):271-285.

19. Borst J, Hendriks J, Xiao Y. CD27 and CD70 in $\mathrm{T}$ cell and B cell activation. Curr Opin Immunol. 2005;17(3):275-281.

20. Alcami A, Symons JA, Smith GL. The vaccinia virus soluble alpha/beta interferon (IFN) receptor binds to the cell surface and protects cells from the antiviral effects of IFN. J Virol. 2000;74(23):11230-11239.

21. Kettle S, Blake NW, Law KM, Smith GL. Vaccinia virus serpins B13R (SPI-2) and B22R (SPI-1) encode $\mathrm{M}(\mathrm{r}) 38.5$ and $40 \mathrm{~K}$, intracellular polypeptides that do not affect virus virulence in a murine intranasal model. Virology. 1995;206(1):136-147.

22. Symons JA, Alcami A, Smith GL. Vaccinia virus encodes a soluble type I interferon receptor of novel structure and broad species specificity. Cell. 1995;81(4):551-560.

23. Tscharke DC, et al. Identification of poxvirus CD8+ $\mathrm{T}$ cell determinants to enable rational design and characterization of smallpox vaccines. J Exp Med. 2005;201(1):95-104.

24. Moutaftsi M, et al. A consensus epitope prediction approach identifies the breadth of murine $\mathrm{T}(\mathrm{CD} 8+)$-cell responses to vaccinia virus. Nat Biotechnol. 2006;24(7):817-819.

25. Salek-Ardakani S, Moutaftsi M, Crotty S, Sette A, Croft M. OX40 drives protective vaccinia virus-specific CD8 T cells. J Immunol. 2008;181(11):7969-7976.

26. Salek-Ardakani S, Croft M. Regulation of CD4 $\mathrm{T}$ cell memory by OX40 (CD134). Vaccine. 2006; 24(7):872-883.

27. Chen L. Co-inhibitory molecules of the B7-CD28 family in the control of T-cell immunity. Nat Rev Immunol. 2004;4(5):336-347.

28. Salek-Ardakani S, Arens R, Flynn R, Sette A, Schoenberger SP, Croft M. Preferential use of B7.2 and not B7.1 in priming of vaccinia virus-specific CD8 T cells. J Immunol. 2009;182(5):2909-2918.

29. Fang M, Sigal LJ. Direct CD28 costimulation is required for $\mathrm{CD} 8+\mathrm{T}$ cell-mediated resistance to an acute viral disease in a natural host. J Immunol. 2006;177(11):8027-8036.

30. Schildknecht A, Miescher I, Yagita $H$, van den Broek M. Priming of CD8 + T cell responses by pathogens typically depends on CD70-mediated interactions with dendritic cells. Eur J Immunol. 2007;37(3):716-728.

31. Hendriks J, et al. During viral infection of the respiratory tract, $\mathrm{CD} 27,4-1 \mathrm{BB}$, and OX40 collectively determine formation of CD8+ memory $\mathrm{T}$ cells and their capacity for secondary expansion. J Immunol. 2005;175(3):1665-1676

32. Salek-Ardakani S, Croft M. Tumor necrosis factor receptor/tumor necrosis factor family members in antiviral CD8 T-cell immunity. J Interferon Cytokine Res. 2010;30(4):205-218.

33. Liu L, Zhong Q, Tian T, Dubin K, Athale SK, Kupper TS. Epidermal injury and infection during poxvirus immunization is crucial for the generation of highly protective $\mathrm{T}$ cell-mediated immunity. Nat Med. 2010;16(2):224-227.

34. Cebere I, et al. Phase I clinical trial safety of DNAand modified virus Ankara-vectored human immunodeficiency virus type 1 (HIV-1) vaccines administered alone and in a prime-boost regime to healthy HIV-1-uninfected volunteers. Vaccine. 2006;24(4):417-425.

35. Barber DL, et al. Restoring function in exhausted CD8 T cells during chronic viral infection. Nature. 2006;439(7077):682-687.

36. Day CL, et al. PD-1 expression on HIV-specific $T$ cells is associated with T-cell exhaustion and disease progression. Nature. 2006;443(7109):350-354.

37. Chen AI, et al. Ox40-ligand has a critical costimulatory role in dendritic cell:T cell interactions. Immunity. 1999;11(6):689-698.

38. Kopf M, et al. OX40-deficient mice are defective in Th cell proliferation but are competent in generating B cell and CTL Responses after virus infection. Immunity. 1999;11(6):699-708.

39. Humphreys IR, et al. OX40 Costimulation Promotes Persistence of Cytomegalovirus-Specific CD8 T Cells: A CD4-Dependent Mechanism. J Immunol. 2007;179(4):2195-2202.

40. Hendriks J, Gravestein LA, Tesselaar K, van Lier RA, Schumacher TN, Borst J. CD27 is required for generation and long-term maintenance of $\mathrm{T}$ cell immunity. Nat Immunol. 2000;1(5):433-440.

41. Hendriks J, Xiao Y, Borst J. CD27 promotes survival of activated $T$ cells and complements CD28 in generation and establishment of the effector T cell pool. J Exp Med. 2003;198(9):1369-1380.

42. Suresh M, et al. Role of CD28-B7 interactions in generation and maintenance of CD8 $\mathrm{T}$ cell memory. J Immunol. 2001;167(10):5565-5573.

43. Bachmann MF, et al. Distinct roles for LFA-1 and CD28 during activation of naive T cells: adhesion versus costimulation. Immunity. 1997;7(4):549-557.

44. McAdam AJ, Farkash EA, Gewurz BE, Sharpe AH. B7 costimulation is critical for antibody class switching and CD8(+) cytotoxic T-lymphocyte generation in the host response to vesicular stomatitis virus. J Virol. 2000;74(1):203-208.

45. Liu Y, Wenger RH, Zhao M, Nielsen PJ. Distinct costimulatory molecules are required for the induction of effector and memory cytotoxic T lymphocytes. J Exp Med. 1997;185(2):251-262.

46. Belyakov IM, et al. Shared modes of protection against poxvirus infection by attenuated and conventional smallpox vaccine viruses. Proc Natl Acad Sci U S A. 2003;100(16):9458-9463.

47. Edghill-Smith Y, et al. Smallpox vaccine-induced antibodies are necessary and sufficient for protection against monkeypox virus. Nat Med. 2005; 11(7):740-747.

48. Xu R, Johnson AJ, Liggitt D, Bevan MJ. Cellular and humoral immunity against vaccinia virus infection of mice. J Immunol. 2004;172(10):6265-6271.

49. Croft M. Co-stimulatory members of the TNFR family: keys to effective T-cell immunity? Nat Rev Immunol. 2003;3(8):609-620.

50. Watts TH. TNF/TNFR family members in costimulation of T cell responses. Annu Rev Immunol. 2005;23:23-68

51. Alcami A, Smith GL. A soluble receptor for interleukin- 1 beta encoded by vaccinia virus: a novel mechanism of virus modulation of the host response to infection. Cell. 1992;71(1):153-167.

52. Zhao Y, De Trez C, Flynn R, Ware CF, Croft M, Salek-Ardakani S. The adaptor molecule MyD88 directly promotes CD8 $\mathrm{T}$ cell responses to vaccinia virus. J Immunol. 2009;182(10):6278-6286. 